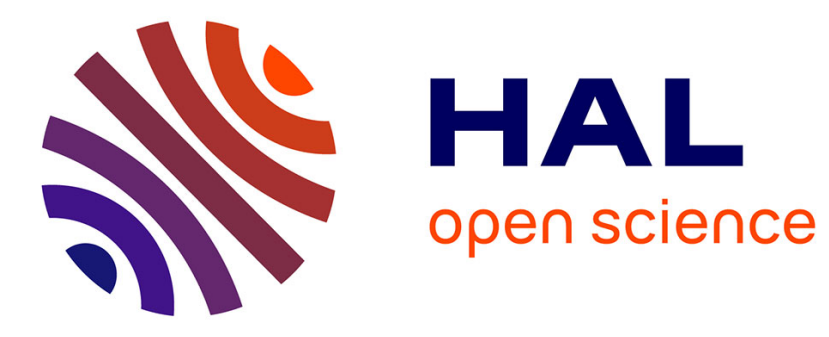

\title{
Nod2 protects remote small intestinal sites in case of colonic inflammation.
}

\author{
Jean-Pierre Hugot, Ziad Al Nabhani, Dominique Berrebi, Christine \\ Martinez-Vinson, Nicolas Montcuquet, Gilles Dietrich, Gurminder Singh, \\ Jerrold R Turner, Chrystele Madre, Maryline Roy, et al.
}

\section{To cite this version:}

Jean-Pierre Hugot, Ziad Al Nabhani, Dominique Berrebi, Christine Martinez-Vinson, Nicolas Montcuquet, et al.. Nod2 protects remote small intestinal sites in case of colonic inflammation.. 2019. hal02790129

\section{HAL Id: hal-02790129 \\ https://hal.inrae.fr/hal-02790129}

Preprint submitted on 5 Jun 2020

HAL is a multi-disciplinary open access archive for the deposit and dissemination of scientific research documents, whether they are published or not. The documents may come from teaching and research institutions in France or abroad, or from public or private research centers.
L'archive ouverte pluridisciplinaire HAL, est destinée au dépôt et à la diffusion de documents scientifiques de niveau recherche, publiés ou non, émanant des établissements d'enseignement et de recherche français ou étrangers, des laboratoires publics ou privés.

\section{(ㅇ)(1) $\$$}

Distributed under a Creative Commons Attribution - NonCommercial - NoDerivatives| 4.0 
3 Ziad Al Nabhani ${ }^{1,2}$, Dominique Berrebi ${ }^{1,2,3, \$}$, Christine Martinez-Vinson ${ }^{3, \$}$, Nicolas

4 Montcuquet $^{4,5}$, Gilles Dietrich ${ }^{6}$, Gurminder $\operatorname{Singh}^{7}$, Jerrold R. Turner ${ }^{7}$, Chrystele Madre ${ }^{1,2,3}$, 5 Maryline $\operatorname{Roy}^{1,2}$, Eric Ogier-Denis ${ }^{1,2}$, Monique Dussaillant ${ }^{1,2,3}$, Nadine Cerf-Bensussan ${ }^{4,5}$, 6 Habib Zouali ${ }^{8}$, Camille Jung ${ }^{1,2,3}$, Fanny Daniel ${ }^{1}$, Frédérick Barreau ${ }^{1,}$, 6\#, Jean-Pierre 7 Hugot $^{1,2,3 \#^{*}}$.

\section{Affiliations :}

${ }^{1}$ Laboratoire d'excellence Inflamex, Université Paris-Diderot Sorbonne Paris-Cité, UMR 11 1149, F-75018 Paris, France.

${ }^{2}$ INSERM, UMR 1149, F-75018 Paris, France.

${ }^{3}$ Assistance Publique Hôpitaux de Paris, services des maladies digestives et respiratoires de l'enfant et service d'anatomie pathologique, Hôpital Robert Debré, F-75019 Paris, France. ${ }^{4}$ INSERM, UMR 989, F-75015 Paris, France.

${ }^{5}$ Université Paris Descartes - Sorbonne Paris Cité, Institut IMAGINE, F-75015 Paris, France.

${ }^{7}$ Department of Pathology, Brigham and Women's Hospital, Harvard Medical School, Boston, Massachusetts.

$20 \quad{ }^{8}$ Fondation Jean-Dausset CEPH, F-75011 Paris, France.

$\$$ and \# equal contribution

*Address for correspondence:

23 Prof Jean-Pierre Hugot,

24 INSERM U843, Hôpital Robert Debré,

2548 Boulevard Sérurier, 75019 Paris, France.

Phone : +331400357 12; Fax : +33140035766

e-mail : jean-pierre.hugot@rdb.aphp.fr

\section{Running title: Nod 2 and remote gut protection}

29 Key words: Nod2/intestinal permeability/Crohn's disease/gut barrier/myosin light chain 30 kinase/CD4 ${ }^{+} \mathrm{T}$ cells.

31 Abbreviations: CD: Crohn's disease; IM: intestinal mucosa (without Peyer's patches); MDP:

32 Muramyl dipeptide; MLCK: myosin light chain kinase; NOD2: nucleotide oligomerization domain 2; RICK: receptor-interacting serine/threonine kinase; TAK1: transforming growth 
bioRxiv preprint first posted online Jan. 3, 2019; doi: http://dx.doi.org/10.1101/510933. The copyright holder for this preprint (which was not peer-reviewed) is the author/funder, who has granted bioRxiv a license to display the preprint in perpetuity. It is made available under a CC-BY-NC-ND 4.0 International license.

34 factor $\beta$-activated kinase 1; TNBS: 2,4,6-trinitrobenzene sulfonic acid; TNF-R, TNF receptor; 35 WT: wild-type.

36 
ABSTRACT

NOD2 mutations are key risk factors for Crohn's disease (CD). NOD2 contributes to intestinal homeostasis by regulating innate and adaptive immunity together with intestinal epithelial function. However, the roles of NOD2 during gut inflammation is not known. We initially observed that NOD2 expression was increased in epithelial cells remote from inflamed areas in CD patients. To explore this finding, Nod2 mRNA expression,

43 inflammation and gut permeability were examined in the small bowel of wild-type (WT), $44 \operatorname{Nod} 2$ knockout and Nod2 mutant mice after rectal instillation of 2,4,6-trinitrobenzene sulfonic acid (TNBS). In WT mice, Nod2 upregulation remote to rectal injury was associated with proinflammatory cytokine expression, recirculating $\mathrm{CD}^{+} \mathrm{T}$-cells, increased paracellular permeability and myosin like chain kinase activity. Nod2 knockout or mutation led to duodenitis and ileitis demonstrating the remote protective role of Nod2. Bone morrow stem cell (BMSC) transplantations indicated that the small intestinal inflammation was due to NOD2 loss in both hematopoietic and non-hematopoietic compartments. As a whole, WT but not mutant NOD2 prevents disease extension at sites remote from the initial intestinal injury. 


\section{Introduction}

Crohn's Disease (CD) is an inflammatory bowel disease (IBD) that can affect any part of the entire gastrointestinal tract. Genetic and epidemiological studies indicate that CD is a complex, multifactorial disorder. Interplay between genetics and the environment promotes development of gut abnormalities of autophagy, reticulum endoplasmic stress, innate and adaptive immune responses, Th-1 and Th-17 polarization, intestinal barrier dysfunction and microbial dysbiosis. ${ }^{1-3}$

Nucleotide oligomerization domain 2 (NOD2, also known as NLR-C2 and CARD15) is the most prominent susceptibility gene for $\mathrm{CD} .{ }^{4,5}$ One-third to one-half of $\mathrm{CD}$ patients have one or more NOD2 mutations. ${ }^{6}$ Wild-type NOD2 is activated by muramyl dipeptides (MDP) which are components of the bacterial cell wall, ${ }^{7}$ but CD-associated NOD2 mutations prevent MDP responses. ${ }^{8} \mathrm{CD}$ can therefore be considered as an immune deficiency with insufficient responses to bacteria. Nevertheless, the exact mechanism by which NOD2 mutations contribute to $\mathrm{CD}$ pathogenesis remains a matter of debate. ${ }^{9-12}$

NOD2 regulates innate and adaptive immunity and intestinal permeability to maintain intestinal homeostasis. ${ }^{13-16}$ Indeed, Nod2 ablation in mice leads to an increased bacterial translocation across the small intestinal epithelium and excessive inflammatory cytokine secretion. ${ }^{14,15}$ This reflects impaired crosstalk between inflammatory cytokine-secreting CD4 ${ }^{+}$ T-cells and epithelial cells that express myosin light chain kinase (MLCK). ${ }^{15}{ }^{17}$ Similarly, increased MLCK activity ${ }^{18}$ and $\mathrm{CD} 4^{+}$T-numbers have been observed in the intestinal mucosa of CD patients, ${ }^{19,20}$ and mouse models show that genetic activation of epithelial MLCK induces increases in mucosal CD4 ${ }^{+} \mathrm{T}_{\text {-numbers. }}{ }^{21}$ Anti-TNF- $\alpha$ antibody treatment restores the intestinal barrier in CD patients. ${ }^{22}$ Impaired epithelial barrier function may therefore be an early event in CD lesions progression.

Here, we show that NOD2 expression in CD patients is not only increased in inflammatory lesions but also at sites remote from injury. To define the mechanisms and impact of this upregulation, we explored the remote consequences on the small intestinal mucosa of a limited rectal injury induced by 2,4,6-trinitrobenzene sulfonic acid (TNBS). 


\section{Results}

Epithelial NOD2 expression is increased in uninflamed mucosa of CD patients.

In CD patients, epithelial NOD2 expression is increased in mildly inflamed areas of the digestive tract, remote from sites of injury. ${ }^{23}$ To confirm NOD2 upregulation in remote areas, we examined expression in ileal and/or cecal biopsies from 17 treatment-naïve pediatric CD cases and five non-inflammatory controls. Although nine CD patients had heterozygous mutations in NOD2 (1007fs $\mathrm{n}=3, \mathrm{R} 702 \mathrm{~W} \mathrm{n}=5$ and $\mathrm{R} 373 \mathrm{C} \mathrm{n}=1$ ), no histological differences were seen between patients with wild type or mutant NOD2. Immunostains using two different antibodies showed that NOD2 was weakly expressed by surface enterocytes and rare mononuclear cells immediately below the epithelium in control ileum (Figure $1 A$ ). In contrast, NOD2 expression was increased in ileum from CD patients (Figure $1 B$ and $C$ ). While NOD2 expression was upregulated in lamina propria mononuclear cells within inflammatory areas, the most prominent increases were in surface and glandular epithelial cells outside of inflammatory lesions (Figure $1 B$ and $C$ ). Analysis of cecal biopsies gave similar results (Figure $1 D-F$ ).

We then determined NOD2 mRNA expression in the epithelial and lamina propria compartments by qPCR after laser microdissection of biopsies from 8 patients. We observed that NOD2 mRNA expression was inversely correlated in the epithelial and lamina propria compartments of the same biopsy (Figure $1 G$ ). In the lamina propria, the average NOD2 copy number was 43.1 in controls (normalized arbitrary units). In CD patients, similar values (43.6) were observed in uninflamed areas whereas NOD2 expression was increased a 5-fold (205.907) in the inflamed ileum. On the contrary, the mean values were 4.91 in epithelial cells of controls and 4.6 in inflamed ileal areas but a 100-fold increase in NOD2 expression (660) was detected in uninflamed ileum. Noteworthy, normal Paneth cells had low NOD2 expression in controls (1.43). This expression was increased by inflammation and in heterotopic colonic Paneth cells but NOD2 was mostly expressed by enterocytes. We thus concluded that NOD2 expression is markedly increased in epithelial cells distant from inflammatory lesions in CD patients.

Gut injury leads to epithelial Nod2 expression and cytokine production at remote sites via $\mathrm{CD4}^{+} \mathrm{T}$-cell activation.

To confirm the expression of epithelial Nod2 in healthy areas distant from intestinal lesions in a mouse model, we treated $\operatorname{Nod} 2$ wild-type $\left(\operatorname{Nod} 2^{\mathrm{WT}}\right)$ mice by an intra-rectal administration of TNBS. Instillation of TNBS in mice is known to induce a severe 
117 inflammation in the distal colon. ${ }^{14}$ Interestingly, TNBS has also been shown to alter the 118 biochemical activity of brush border enzymes (sucrase isomaltase and aminopeptidase), mucins and cytokines levels in the small bowel (i.e. at a significant distance from the gut injury) without histological lesions. ${ }^{24}$ Three days after instillation, mice were sacrificed and

121 the severity of inflammation was assessed (Figure 2). In the distal colon, TNBS

122 administration induced a robust inflammation as evidenced by decreased body weight, 123 increased disease activity index (DAI), reduced colon length and high macroscopic Wallace 124 damage scores (Figure 2A-D). Consistent with this phenotype, expression levels of TNF- $\alpha$, IFN- $\gamma$ and IL-12 were increased (Figure $2 E$ ) at the site of colonic inflammation.

We next examined the small bowel but we did not find any overt inflammatory lesion in the duodenum or ileum (Figure $2 F$ and $G$ ) despite increased TNF- $\alpha$, IFN- $\gamma$ and IL-12 128 proteins (Figure $2 H$ ) and mRNA (Figure 2I) levels. As observed in CD patients, expression of Nod2 was increased in the duodenum, ileum and the uninflamed part of the colon remote from rectal injury (Figure 2I). We hypothesized that this effect was consecutive to the recirculation of $\mathrm{CD}^{+}$pro-inflammatory T-cells in the gut mucosa. We therefore treated TNBS-challenged mice with anti-CD4 ${ }^{+}$monoclonal antibodies to reduce the number of $\mathrm{CD} 4^{+} \mathrm{T}$-cells in the small bowel (Figure $2 J$ ). This treatment only partially improved the colitis but restored normal levels of Nod2 and inflammatory cytokines in the duodenum and ileum (Figure 2A-I).

IFN- $\gamma$ and TNF- $\alpha$ increase intestinal paracellular permeability via MLCK activation. We therefore investigated whether the paracellular permeability of the small bowel was affected in TNBS treated mice. ${ }^{25-27}$ Paracellular permeability as well as long Mylk mRNA expression were increased in both duodenum and ileum but returned to normal after CD4 ${ }^{+} \mathrm{T}$ cell depletion (Figures $2 I$ and $K$ ). Treatment of mice with an inhibitor of inflammatory $\mathrm{CD}^{+}$ T-cells recirculation (FTY720) limited paracellular permeability increases in the duodenum and the ileum further indicating that a recirculation of T-cells from the rectal inflammatory lesions is likely responsible for the remote small bowel barrier loss (Figure $2 L$ ).

Of note, given the abundance of immune cells in inflamed areas, higher levels of epithelial NOD2 would be expected in the inflamed bowel of CD patients if the expression of epithelial NOD2 was under the control of $\mathrm{CD}^{+}$T-cells. We therefore determined the populations of immune cells present in the lamina propria of CD patients by immunostaining.

147 Consistent with data collected in mice, lamina propria $\mathrm{CD}^{+}$T-cell numbers were not 148 increased in areas with the highest grades of inflammation. Most immune cells present in the 149 lamina propria at these sites within the ileum (Figures $3 A$ and $B$ ) and the colon (Figure $3 C$ and 
150 D) were $\mathrm{CD}_{163^{+}}$macrophages. Consistently, $\mathrm{CD} 4^{+} \mathrm{T}$-cells predominated in areas with low 151 grade inflammation.

\section{MLCK activity is necessary to maintain the pro-inflammatory status of the small}

\section{intestinal mucosa.}

Since pro-inflammatory cytokines such as IL- $1 \beta$, TNF- $\alpha$ and IFN- $\gamma$ can alter the paracellular permeability of the intestinal epithelium by increasing the expression and activity of long MLCK, we explored the role of MLCK in barrier function. ${ }^{17,27-30}$ Treatment of mice with ML-7 (an inhibitor of MLCK) had only a limited impact on the severity of TNBSinduced colitis (Figure 4A-E). In contrast, MLCK inhibition restored normal TNF- $\alpha$, IFN- $\gamma$, IL-1 $\beta$, IL-12 expression (mRNA and protein), Mylk and Nod2 mRNA transcription, and paracellular permeability in the duodenum and the ileum (Figures $4 F-H$ ). Similarly, knockout mice lacking long MLCK developed a slightly less severe colitis compared to WT mice (Figure 4I-L) and did not develop increased duodenal or ileal paracellular permeability (Figure $4 M$ ). These data confirm that MLCK activity is responsible for the gut barrier defect remote from inflammatory lesions.

\section{NOD2 maintains the barrier integrity on remote small bowel.}

We have previously shown that stimulation of epithelial NOD2 with MDP allows the maintenance of the gut barrier. ${ }^{17} \operatorname{Nod} 2{ }^{\mathrm{WT}}$ mice were treated with MDP for 2 consecutive days before experimentation. Intraperitoneal injection of rhodamine-labelled MDP confirmed the ability of MDP to enter the enterocytes (Figures 5A-C). NOD2 stimulation reduced the disease activity index, colonic length, Wallace damage scores and pro-inflammatory cytokine expression without any effects on body weight loss after rectal TNBS infusion (Figures $5 D$ $H$ ). In contrast, in the small bowel, MDP treatment normalized mRNA (Figure 5I) and protein (Figure $5 J$ ) levels of pro-inflammatory cytokines as well as the paracellular permeability (Figure $5 K$ ). As expected, MDP did not affect the increase in Nod2 expression (Figure 5I).

Ablation of $\operatorname{Nod} 2$ in mice $\left(\operatorname{Nod} 2^{\mathrm{KO}}\right)$ results in increased paracellular and transcellular permeability across Peyer's patches ${ }^{14,15}$ and higher percentages of pro-inflammatory $\mathrm{CD} 4^{+} \mathrm{T}$ cells ${ }^{14}$ but $\operatorname{Nod} 2^{\mathrm{KO}}$ mice are only slightly more susceptible to TNBS-induced colitis (Figures $6 A-D) .{ }^{14}$ However, while TNBS-treated Nod2 ${ }^{\mathrm{WT}}$ mice exhibit no lesion in the small bowel (Figure $2 \mathrm{~F}$ ), two thirds of $\mathrm{Nod} 2^{\mathrm{KO}}$ mice showed overt duodenal inflammatory lesions as shown by a slight infiltration of scattered neutrophils in the lamina propria (Figure $6 E$ and $F$ ). In the ileum, we observed a marked inflammation in $5 / 8 \mathrm{Nod} 2^{\mathrm{KO}}$ mice, an infiltration of 
neutrophils and mononuclear cells in the villi and the crypts and a loss of muco-secretion. In addition, $\operatorname{Nod} 2^{K O}$ mice exhibited an increased expression of pro-inflammatory cytokines in the duodenum and the ileum (Figure $6 G$ ). In contrast to $N o d 2^{\mathrm{WT}}$ mice, treatment with MDP did not correct the expression of pro-inflammatory cytokines nor the increased permeability in the intestine of $\operatorname{Nod} 2^{\mathrm{KO}}$ mice (Figures $7 A-F$ ). These findings indicate that the absence of Nod2 leads to the development of remote lesions distant to rectal injury.

In humans, $\mathrm{CD}$ is characterized by gastrointestinal skip lesions. Among the NOD2 genetic polymorphisms associated with $\mathrm{CD}$, the 3020insC mutation encodes for a truncated (1007fs) protein. As described in $N o d 2^{\mathrm{KO}}$ mice, $N o d 2^{2939 \mathrm{ins} C}$ mice -which are homozygotes for a mutation homologous to the Human 3020insC variant ${ }^{12}$-developed a slightly more severe colitis after TNBS administration (Figure 6A-D). We observed inflammatory lesions in the duodenum and ileum of respectively $4 / 5$ and 6/8 Nod2 $2^{2939 i n s C}$ mice after TNBS instillation (Figures $6 E$ and $F$ ). Treatment of $N o d 2^{2939 \text { insC }}$ mice with MDP did not reduce the expression of pro-inflammatory cytokines and the increased permeability in the small intestine (Figure $7 A-F)$. We thus concluded that mice carrying a CD associated mutation of NOD2 are not able to contain the intestinal inflammation where the primitive inflammatory lesions occurred. ${ }^{12}$

Since $\operatorname{Nod} 2^{\mathrm{KO}}$ mice present a microbiota dysbiosis, we studied the contribution of gut Sharing the dysbiotic microbiota associated with the deletion of $\operatorname{Nod} 2$ in $\operatorname{Nod} 2^{\mathrm{WT}}$ mice did not change the severity of TNBS-induced colitis (Figures $7 G-H$ ) and the increased paracellular permeability of the ileal mucosa (Figure $7 I$ ). This finding suggests that the microbiota plays no major role on remote intestinal sites.

Both hematopoietic and non-hematopoietic Nod2 regulate the small bowel function remote from colonic injury.

NOD2 is detected in intestinal cells of hematopoietic and non-hematopoietic-origins. ${ }^{35}$

To compare the role of hematopoietic vs non-hematopoietic NOD2 in the small bowel during colitis, we compared Nod2 chimeric mice after bone marrow stem cell (BMSC) transfer from $\operatorname{Nod} 2^{\mathrm{KO}}$ to $\operatorname{Nod} 2^{\mathrm{WT}}$ mice $(\mathrm{KO} \rightarrow \mathrm{WT})$ and $N o d 2^{\mathrm{WT}}$ to $N o d 2^{\mathrm{KO}}(\mathrm{WT} \rightarrow \mathrm{KO})$ to control mice

213 transplanted with BMSC of the same genetic background (WT $\rightarrow \mathrm{WT}$ and $\mathrm{KO} \rightarrow \mathrm{KO}$ ) (Figures

$2148 A-C){ }^{32}$ Chimeric mice were then challenged with TNBS three months after BMSC transplantation. Chimeric mice transplanted with $\operatorname{Nod} 2^{\mathrm{KO}}$ BMSC were slightly more susceptible to TNBS-induced colitis than chimeric mice grafted with Nod2 ${ }^{\mathrm{WT}}$ BMSC (Figures 
receiving $\mathrm{WT}(\mathrm{WT} \rightarrow \mathrm{WT}$ and $\mathrm{WT} \rightarrow \mathrm{KO}$ chimeric mice altogether referred to $\mathrm{WT} \rightarrow \mathrm{WT} / \mathrm{KO}$ mice) or $\operatorname{Nod} 2^{\mathrm{KO}}$ bone morrow $(\mathrm{KO} \rightarrow \mathrm{KO}$ and $\mathrm{KO} \rightarrow \mathrm{WT}$ chimeric mice referred to $\mathrm{KO} \rightarrow \mathrm{KO} / \mathrm{WT}$ mice). However, the Wallace score, IFN- $\gamma$ and TNF- $\alpha$ levels were higher in colonic inflamed mucosae of chimeric mice receiving $\operatorname{Nod} 2^{\mathrm{KO}}$ BMSC compared to mice receiving Nod $2^{\mathrm{WT}}$ BMSC (Figures $\left.8 D-H\right)$.

Interestingly, ablation of $\operatorname{Nod} 2$ in the hematopoietic lineages led to a more frequent and more severe inflammation in the ileum compared to chimeric mice expressing Nod2 in the hematopoietic cells (Figure 8I). In parallel, expression levels of pro-inflammatory cytokines levels and paracellular permeability were higher in mice deficient for Nod2 in BMSC (Figures $8 J$ and $K$ ). Consistent with the anti-inflammatory role of NOD2 in the intestinal mucosa ${ }^{36}$, treatment with MDP improved the colonic inflammation but also the severity of the small bowel inflammation and the expression in inflammatory cytokines in the ileum only in chimeric mice expressing Nod2 in their hematopoietic compartment (Figures $8 H-J)$. However, chimeric mice expressing NOD2 in their radio-resistant compartment showed reduced paracellular permeability after MDP treatment regardless of the presence of NOD2 in hematopoietic cells (Figure $8 K$ ). This provides additional evidence that both hematopoietic and non-hematopoietic NOD2 exerts a protective function on the gut barrier. ${ }^{17}$

\section{Discussion}

A "leaky gut" is a common feature of several conditions associated with NOD2 mutations including CD. Here we show that NOD2 protects the small intestine not only in injured areas but also in areas remote from gut mucosal lesions. Indeed, NOD2 controls the paracellular permeability all along the digestive tract to contain the inflammation to local injuries and prevents its dissemination throughout the intestine.

We first observed that NOD2 expression was increased remote from primary inflammatory lesions in naïve pediatric CD patients. Interestingly, the increase in NOD2 expression was not restricted to immune cells in inflammatory areas as it was also detected in epithelial cells remote from CD lesions. We therefore hypothesized that epithelial NOD2 may have a specific role in healthy intestinal areas and explored the intestinal barrier remote from local injuries in mice.

The TNBS-induced colitis is a well-known model of self-limited inflammation. Although TNBS is administered in the rectum, it also alters the small intestine without any overt histological lesions in rats suggesting a remote effect of the colitis on the upper 
intestine. $^{24,}{ }^{37}$ In wild-type mice, we did not find any overt duodenitis or ileitis but we observed an increase in pro-inflammatory cytokines (TNF- $\alpha$ and IFN- $\gamma$ ) concentration, intestinal permeability and epithelial Nod 2 expression in the small bowel. These effects were reversed by anti-CD4 ${ }^{+}$antibodies or inhibitor of recirculated $\mathrm{CD} 4^{+} \mathrm{T}$-cells suggesting that they were consecutive to the recirculation of T-cells activated in the injured mucosa. Pharmacologic or genetic MLCK inhibition limited permeability increases, indicating that MLCK activation is a key component of the inflammatory response. Specifically, gut permeability augmented TNF- $\alpha$ and IFN- $\gamma$ expression and altered lamina propria immune status. $^{21}$ Conversely, pro-inflammatory cytokines increased paracellular permeability by stimulating MLCK expression and activity. ${ }^{28,29}$

Local colonic injury leads to the disruption of the small bowel barrier. Since Nod2 is known to protect the gut barrier by inhibiting MLCK $^{15}$ and because it was over-expressed in the small intestine, we supposed that it could restrain the leaky gut phenotype to the injured mucosa. MDP-induced activation of Nod2 fully corrected the impairment of the small bowel indicating that Nod2 plays a protective role along the small bowel. Recirculation of activated T-cells increases the gut permeability but also induces NOD2 expression which, in turn, strengthens the gut barrier. Interestingly, NOD2 seems to have little effect on the colitis itself. The severity of the inflammation may thus limit the effect of Nod2.

In contrast to WT mice, Nod2-deficient or mutated mice developed overt inflammatory lesions in the small bowel during TNBS-induced colitis, thus confirming the relevance of NOD2 in the protection of the gut barrier. Using BMSC transfer experiments (from $\operatorname{Nod} 2^{\mathrm{WT}}$ to $\operatorname{Nod} 2^{\mathrm{KO}}$ mice and vice-versa), we showed that both hematopoietic and nonhematopoietic NOD2 are necessary to protect the small bowel mucosa.

To the best of our knowledge, the role of NOD2 remote to colonic inflammation had never been demonstrated. In CD, Th- 1 oriented $\mathrm{CD} 4^{+} \mathrm{T}$ cells appear to be key effectors of gut inflammation and NOD2 expression ${ }^{38}$ and most treatments (anti-inflammatory drugs, immune-suppressors and anti-TNF- $\alpha$ antibodies) target $\mathrm{CD}^{+} \mathrm{T}$ cells. For instance, TNF- $\alpha$ antagonists diminish the severity of the disease and restore the gut barrier function. ${ }^{22,}{ }^{39}$ In our model, Nod2 invalidation in the hematopoietic compartment is sufficient to promote a barrier defect which is consistent with reported cases of CD patients cured by allogenic or autologous hematopoietic stem cell transplantation. ${ }^{40}$ However, activation of epithelial NOD2 may also counteract the effect of IFN- $\gamma$ and TNF- $\alpha$ suggesting that treatment of patients not carrying mutations in NOD2 with NOD2 agonists could activate the negative feedback loop to prevent the propagation of the inflammation and the skip lesions defining $\mathrm{CD} .{ }^{41}$ 


\section{Material and Methods}

\section{Patients and biopsies.}

Intestinal biopsies were obtained from 17 untreated children during routine endoscopies performed to establish CD diagnosis. Controls were histologically normal digestive biopsies obtained from 5 children without inflammatory bowel disease. For each participant, one or two biopsies from the ileum and/or cecum were sampled. Biopsies were either immediately frozen and later stained with toluidine blue or fixed in 4\%-phosphate-buffered formalin and stained with hematoxylin and eosin. All biopsies were graded histologically so that immunohistochemistry and laser microdissection could be correlated with disease severity. NOD2 immunostaining was performed as previously described with two different rabbit polyclonal antibodies (Cayman Chemical and a gift from $G$ Thomas CEPH). ${ }^{23}$ Laser microdissection was performed on $7 \mu \mathrm{m}$ sections obtained from the frozen biopsies. After verification of the quality of tissues and the absence of ulcers, surface epithelial cells and lamina propria cells were laser-microdissected using a Leica ${ }^{\mathrm{R}}$ AS LMD system (Leica microsystems) in less than one hour. A mean of 500 cells were microdissected from each of the specimens (range 100-1000 cells) and stored in Trizol ${ }^{\mathrm{R}}$ reagent (Invitrogen, Groningen, The Netherlands). The study was approved by the ethic committee "de protection des personnes" (Saint Louis Hospital, Paris, France) and all the parents of participants provided a signed informed consent.

\section{Animal models.}

Housing and experiments were conducted according to institutional animal healthcare 308 (Comité Régional d'Ethique en matière d'Expérimentation Animale no. 4, Paris, France). C57BL/6 wild-type (WT), Nod2 null allele (Nod2 ${ }^{\mathrm{KO}}$ ) and $\operatorname{Nod} 2^{2939 i n s C}$ mice (homozygotes for a mutation homologous to the Human 3020insC variant) together with long $M L C K$ deficient mice $\left(\mathrm{MLCK}^{K O}\right)$ were generated or hosted in a pathogen free animal facility. ${ }^{12,14,26}$ The animal facility was monitored every six months in accordance with the full set of FELASA

313 high standard recommendations. The putative impact of Nod2-related dysbiosis on the studied 314 phenotypes was assessed using WT and $N o d 2^{K O}$ mice cohoused for 6 weeks in the same cage where indicated. ${ }^{33,42}$

For the construction of chimeric mice, five million bone marrow stem cells (BMSC) were isolated from WT Ly5.1 or $\operatorname{Nod} 2^{\mathrm{KO}}$ Ly5.2 mice and injected intravenously either into 
WT Ly5.1 or $\operatorname{Nod} 2^{\mathrm{KO}}$ Ly.5.2 lethally-irradiated recipients. ${ }^{30,}{ }^{32}$ Chimerism was verified at week 12 by flow cytometry using Ly5.1 and Ly5.2 congenic markers (Figure 8A-C). ${ }^{35}$ before experimentation and 24hours after TNBS administration. ${ }^{15}$ The effectiveness of CD4 + depletion in Peyer's plates is shown in Figure $2 J$. To inhibit the recirculation of $\mathrm{CD}^{+}{ }^{+} \mathrm{T}$-cells, mice were treated i.p. with FTY720 (3mg/kg; Sigma, France $)^{43} 0,1,2$ and 3 days after TNBS infusion.

MLCK inhibition was achieved by ip injection of ML-7, $2 \mathrm{mg} / \mathrm{kg}$ body weight (Sigma, France) twice daily during 4 days before experiments and 24 hours after TNBS administration. ${ }^{15}$ To investigate the effect of Nod2 stimulation, adult mice were pre-treated i.p with muramyl dipeptide (MDP, 100 $\mathrm{g} / \mathrm{mice} / \mathrm{day}$; Sigma, France) for 2 consecutive days before experimentation and 24 hours after TNBS administration. ${ }^{35}$

\section{Colitis induction.}

Colitis was induced in 12 weeks old mice by a single intra-rectal administration of 2,4,6-trinitrobenzene sulfonic acid (TNBS, Sigma, France), which was dissolved in ethanol (50:50 vol/vol) at a dose of $120 \mathrm{mg} / \mathrm{kg}$ body weight under anaesthesia. Groups used as controls (vehicle) received an equal volume of PBS and Ethanol (50:50 vol/vol) intra-rectally. A $100 \mu \mathrm{l}$ aliquot of the freshly prepared solution was injected into the colon, $4 \mathrm{~cm}$ from the anus, using a $3.5 \mathrm{~F}$ polyethylene catheter as previously described. ${ }^{14}$ Body weight loss and disease activity index were monitored before and $72 \mathrm{~h}$ after TNBS administration. Mice were sacrificed by cervical dislocation. Colonic length and macroscopic damage Wallace score were recorded. ${ }^{44}$

Duodenal and ileal samples were fixed in 4\%-phosphate-buffered formalin and embedded in paraffin. Five-micrometer sections were cut and stained with hematoxylin and eosin. Grading of the inflammatory scores were performed in blind fashion according the follow criteria $^{45}: 0$, no sign of inflammation; 1 , very low level of leukocyte infiltration; 2 , low level of leukocyte infiltration; 3, high level of leukocyte infiltration, high vascular density, and thickening of the colon wall; 4, transmural infiltration, loss of goblet cells, high vascular density, and thickening of the colon wall in less than half of circumference ; 5 necrosis of more than half the circumference and transmural inflammation.

Myeloperoxydase (MPO) expression was detected by immunohistochemistry. All sections were deparaffinized in xylene, rehydrated, incubated in 3\% hydrogen peroxide for endogenous peroxidase removal, and heated for 10 minutes in sub-boiling $10 \mathrm{mM}$ citrate 
buffer ( $\mathrm{pH}$ 6.0) for antigen retrieval. Then, sections were processed using the ImmPRESS polymer detection systems \& reagents (Vector Laboratories, Burlingame, Ca), using antiMPO antibody (Abcam, Cambridge, UK).

\section{Muramyl dipeptide localization.}

Mice were injected intraperitoneally with $300 \mu \mathrm{g}$ of rhodamine-labeled muramyl dipeptide (MDP, InvivoGen, San Diego, CA). Two hours later, mice were anesthetized with isofurane (Centre Specialités Pharmaceutiques, Moussy-le-Neuf, France) and sacrified. Ileal and duodenal samples were collected and rinsed with ice-cold PBS (ThermoFisher, Waltham, MA). Tissue was frozen in liquid nitrogen using HistoLab OCT cryomount (Histolab, Gothengurg, Sweden), 10 $\mu$ m-thick cryosections were cut and then fixed in 4\%. PFA. MDPrhodamine localization was detected by fluorescence confocal microscopy (confocal sp8, Leica, Frankfurt am Main, Germany).

\section{Paracellular permeability measurement.}

To measure the intestinal permeability, biopsies from duodenal and ileal mucosa were mounted in a Ussing chamber exposing $0.196 \mathrm{~cm}^{2}$ of tissue surface to $1.5 \mathrm{ml}$ of circulating oxygenated Ringer solution at $37^{\circ} \mathrm{C}$. Paracellular permeability was assessed by measuring the mucosal-to-serosal flux of $4 \mathrm{kDa}$ FITC-dextran (Sigma, France).$^{30}$

ELISA.

Biopsies of duodenum, ileum and colon from different mice models were collected and washed with cold PBS. These biopsies were then homogenized using an ultra-thurax in 1 $\mathrm{ml}$ of PBS1X and, the concentration of protein was determined using commercial kit (Biorad, Marnes la Coquette, France). IFN- $\gamma$, IL-1 $\beta$, IL-12 and TNF- $\alpha$ protein levels in the intestine were determined by ELISA according to manufacturer's instructions (BD Biosciences). ${ }^{46}$

\section{DNA extraction and real time quantitative PCR.}

After extraction by the NucleoSpin RNA II Kit (Macherey-Nagel, France), total RNAs were converted to cDNA using random hexonucleotides and then used for RT-PCR (Invitrogen). We conducted qPCR with QuantiTect SYBR Green PCR Kit (Applied, France) using sense and antisense primers specific for G3PDH, the long MLCK isoform (specifically expressed by epithelial cells), Ifn- $\gamma, I l-1 \beta, I l-12, N O D 2, M y l k$ and Tnf- $\alpha$ (primers used available in table 1). The cycle threshold $(\mathrm{Ct})$ was defined as the number of cycles at which the normalized fluorescent intensity passed the level of 10 times the standard deviations of the baseline emission calculated on the first 10 PCR cycles. Results are expressed as $2^{-\Delta \Delta C t}$ as previously described. ${ }^{33}$ For RNA samples obtained by laser microdissection, NOD2 expression was measured in triplicate and normalized using the Abelson housekeeping gene. 
To derive a relative number of mRNA molecules, a titration curve was established with NOD2 plasmids (from 1 to $10^{6}$ copy/microliters).

\section{Statistical analysis.}

For all the analysis, multigroup comparisons were performed using one-way ANOVA statistics with Bonferroni correction for multiple comparisons where an unpaired t-test assuming the Gaussian distribution was applied. The Gaussian distribution was tested by the Kolmogorov-Smirnov test. Statistical analyzes were performed using GraphPad Prism 7.00 (GraphPad Software). A two-sided P-value $<0.05$ was considered statistically significant. All authors reviewed the data and approved the final manuscript.

\section{Acknowledgements.}

We thank Latifa Ferkdadji, Michel Peuchmaur, Xavier Fund, Anh Thu Gaston, Guillaume Even and Céline Berraud for their support and assistance. Financial support was provided by INSERM, Université Paris Diderot, Assistance Publique Hopitaux de Paris, Association François Aupetit and Investissements d'Avenir programme ANR-11-IDEX-0005-

\section{Author contributions:}

405 Study design and concept: ZA, DB, HZ, FB, JPH; Data acquisition: ZA, DB, CMV, NM, CM, 406 MR, MD, HZ, CJ, FB; Analysis and interpretation: ZA, DB, CMV, NM, GD, JRT, CM, MR, 407 NCB, CJ, FB, JPH; Writing of the manuscript: ZA, GD, JRT, NCB, FB, JPH; Obtained 408 funding: JPH; Technical support: DB, CMV, GS, GD, NM, CM, MR, EOD, MD, CJ; Study 409 supervision: DB, FB, JPH.

\section{Authors have no conflict of interest to declare.}




\section{References.}

1. Treton X, Pedruzzi E, Guichard C, Ladeiro Y, Sedghi S, Vallee M, Fernandez N, Bruyere E, Woerther PL, Ducroc R, Montcuquet N, Freund JN, Van Seuningen I, Barreau F, Marah A, Hugot JP, Cazals-Hatem D, Bouhnik Y, Daniel F, Ogier-Denis E. Combined nadph oxidase 1 and interleukin 10 deficiency induces chronic endoplasmic reticulum stress and causes ulcerative colitis-like disease in mice. PLoS One 2014;9:e101669.

2. Thachil E, Hugot JP, Arbeille B, Paris R, Grodet A, Peuchmaur M, Codogno P, Barreau F, Ogier-Denis E, Berrebi D, Viala J. Abnormal activation of autophagyinduced crinophagy in paneth cells from patients with crohn's disease. Gastroenterology 2012.

3. Khor B, Gardet A, Xavier RJ. Genetics and pathogenesis of inflammatory bowel disease. Nature 2011;474:307-17.

4. Hugot JP, Chamaillard M, Zouali H, Lesage S, Cezard JP, Belaiche J, Almer S, Tysk C, O'Morain CA, Gassull M, Binder V, Finkel Y, Cortot A, Modigliani R, LaurentPuig P, Gower-Rousseau C, Macry J, Colombel JF, Sahbatou M, Thomas G. Association of nod2 leucine-rich repeat variants with susceptibility to crohn's disease. Nature 2001;411:599-603.

5. Ogura Y, Bonen DK, Inohara N, Nicolae DL, Chen FF, Ramos R, Britton H, Moran T, Karaliuskas R, Duerr RH, Achkar JP, Brant SR, Bayless TM, Kirschner BS, Hanauer $\mathrm{SB}$, Nunez G, Cho JH. A frameshift mutation in nod2 associated with susceptibility to crohn's disease. Nature 2001;411:603-6.

6. Lesage S, Zouali H, Cezard JP, Colombel JF, Belaiche J, Almer S, Tysk C, O'Morain C, Gassull M, Binder V, Finkel Y, Modigliani R, Gower-Rousseau C, Macry J, Merlin F, Chamaillard M, Jannot AS, Thomas G, Hugot JP. Card15/nod2 mutational analysis and genotype-phenotype correlation in 612 patients with inflammatory bowel disease. Am J Hum Genet 2002;70:845-57.

7. Al Nabhani Z, Dietrich G, Hugot JP, Barreau F. Nod2: The intestinal gate keeper. PLoS Pathog 2017;13:e1006177.

8. Inohara N, Nunez G. Nods: Intracellular proteins involved in inflammation and apoptosis. Nat Rev Immunol 2003;3:371-82.

9. Watanabe T, Kitani A, Murray PJ, Strober W. Nod2 is a negative regulator of toll-like receptor 2-mediated t helper type 1 responses. Nat Immunol 2004;5:800-8.

10. Kobayashi KS, Chamaillard M, Ogura Y, Henegariu O, Inohara N, Nunez G, Flavell RA. Nod2-dependent regulation of innate and adaptive immunity in the intestinal tract. Science 2005;307:731-4.

11. Eckmann L, Karin M. Nod2 and crohn's disease: Loss or gain of function? Immunity 2005;22:661-7.

12. Maeda S, Hsu LC, Liu H, Bankston LA, Iimura M, Kagnoff MF, Eckmann L, Karin M. Nod2 mutation in crohn's disease potentiates nf-kappab activity and il-1beta processing. Science 2005;307:734-8.

13. Buhner S, Buning C, Genschel J, Kling K, Herrmann D, Dignass A, Kuechler I, Krueger S, Schmidt HH, Lochs H. Genetic basis for increased intestinal permeability in families with crohn's disease: Role of card15 3020insc mutation? Gut 2006;55:3427.

14. Barreau F, Meinzer U, Chareyre F, Berrebi D, Niwa-Kawakita M, Dussaillant M, Foligne B, Ollendorff V, Heyman M, Bonacorsi S, Lesuffleur T, Sterkers G, Giovannini M, Hugot JP. Card15/nod2 is required for peyer's patches homeostasis in mice. PLoS One 2007;2:e523. 
15. Barreau F, Madre C, Meinzer U, Berrebi D, Dussaillant M, Merlin F, Eckmann L, Karin M, Sterkers G, Bonacorsi S, Lesuffleur T, Hugot JP. Nod2 regulates the host response towards microflora by modulating t cell function and epithelial permeability in mouse peyer's patches. Gut 2010;59:207-17.

16. Barreau F, Hugot J. Intestinal barrier dysfunction triggered by invasive bacteria. Curr Opin Microbiol 2014;17C:91-98.

17. Al Nabhani Z, Montcuquet N, Roy M, Dussaillant M, Hugot JP, Barreau F. Complementary roles of nod2 in hematopoietic and nonhematopoietic cells in preventing gut barrier dysfunction dependent on mlck activity. Inflamm Bowel Dis 2017;23:1109-1119.

18. Blair SA, Kane SV, Clayburgh DR, Turner JR. Epithelial myosin light chain kinase expression and activity are upregulated in inflammatory bowel disease. Lab Invest 2006;86:191-201.

19. Reikvam DH, Perminow G, Lyckander LG, Gran JM, Brandtzaeg P, Vatn M, Carlsen HS. Increase of regulatory t cells in ileal mucosa of untreated pediatric crohn's disease patients. Scand J Gastroenterol 2011;46:550-60.

20. Parronchi P, Romagnani P, Annunziato F, Sampognaro S, Becchio A, Giannarini L, Maggi E, Pupilli C, Tonelli F, Romagnani S. Type 1 thelper cell predominance and interleukin-12 expression in the gut of patients with crohn's disease. Am J Pathol 1997; 150:823-32.

21. Su L, Shen L, Clayburgh DR, Nalle SC, Sullivan EA, Meddings JB, Abraham C, Turner JR. Targeted epithelial tight junction dysfunction causes immune activation and contributes to development of experimental colitis. Gastroenterology 2009;136:551-63.

22. Suenaert P, Bulteel V, Lemmens L, Noman M, Geypens B, Van Assche G, Geboes K, Ceuppens JL, Rutgeerts P. Anti-tumor necrosis factor treatment restores the gut barrier in crohn's disease. Am J Gastroenterol 2002;97:2000-4.

23. Berrebi D, Maudinas R, Hugot JP, Chamaillard M, Chareyre F, De Lagausie P, Yang C, Desreumaux P, Giovannini M, Cezard JP, Zouali H, Emilie D, Peuchmaur M. Card15 gene overexpression in mononuclear and epithelial cells of the inflamed crohn's disease colon. Gut 2003;52:840-6.

24. Barada KA, Mourad FH, Sawah SI, Khoury C, Safieh-Garabedian B, Nassar CF, Saade NE. Localized colonic inflammation increases cytokine levels in distant small intestinal segments in the rat. Life Sci 2006;79:2032-42.

25. Zolotarevsky Y, Hecht G, Koutsouris A, Gonzalez DE, Quan C, Tom J, Mrsny RJ, Turner JR. A membrane-permeant peptide that inhibits mlc kinase restores barrier function in in vitro models of intestinal disease. Gastroenterology 2002;123:163-72.

26. Clayburgh DR, Barrett TA, Tang Y, Meddings JB, Van Eldik LJ, Watterson DM, Clarke LL, Mrsny RJ, Turner JR. Epithelial myosin light chain kinase-dependent barrier dysfunction mediates $t$ cell activation-induced diarrhea in vivo. J Clin Invest 2005;115:2702-15.

27. Wang F, Graham WV, Wang Y, Witkowski ED, Schwarz BT, Turner JR. Interferongamma and tumor necrosis factor-alpha synergize to induce intestinal epithelial barrier dysfunction by up-regulating myosin light chain kinase expression. Am J Pathol 2005;166:409-19.

28. Al-Sadi R, Ye D, Dokladny K, Ma TY. Mechanism of il-1beta-induced increase in intestinal epithelial tight junction permeability. J Immunol 2008;180:5653-61.

29. Wang F, Schwarz BT, Graham WV, Wang Y, Su L, Clayburgh DR, Abraham C, Turner JR. Ifn-gamma-induced tnfr2 expression is required for tnf-dependent intestinal epithelial barrier dysfunction. Gastroenterology 2006;131:1153-63. 
30. Jung C, Meinzer U, Montcuquet N, Thachil E, Chateau D, Thiebaut R, Roy M, Alnabhani Z, Berrebi D, Dussaillant M, Pedruzzi E, Thenet S, Cerf-Bensussan N, Hugot JP, Barreau F. Yersinia pseudotuberculosis disrupts intestinal barrier integrity through hematopoietic tlr-2 signaling. J Clin Invest 2012;122:2239-51.

31. Mondot S, Barreau F, Al Nabhani Z, Dussaillant M, Le Roux K, Dore J, Leclerc M, Hugot JP, Lepage P. Altered gut microbiota composition in immune-impaired nod2(-/) mice. Gut 2012;61:634-5.

32. Alnabhani Z, Hugot JP, Montcuquet N, Le Roux K, Dussaillant M, Roy M, Leclerc M, Cerf-Bensussan N, Lepage P, Barreau F. Respective roles of hematopoietic and nonhematopoietic nod2 on the gut microbiota and mucosal homeostasis. Inflamm Bowel Dis 2016;22:763-73.

33. Al Nabhani Z, Lepage P, Mauny P, Montcuquet N, Roy M, Le Roux K, Dussaillant M, Berrebi D, Hugot JP, Barreau F. Nod2 deficiency leads to a specific and transmissible mucosa-associated microbial dysbiosis which is independent of the mucosal barrier defect. J Crohns Colitis 2016;10:1428-1436.

34. Couturier-Maillard A, Secher T, Rehman A, Normand S, De Arcangelis A, Haesler R, Huot L, Grandjean T, Bressenot A, Delanoye-Crespin A, Gaillot O, Schreiber S, Lemoine Y, Ryffel B, Hot D, Nunez G, Chen G, Rosenstiel P, Chamaillard M. Nod2mediated dysbiosis predisposes mice to transmissible colitis and colorectal cancer. $\mathrm{J}$ Clin Invest 2013.

35. Alnabhani Z, Montcuquet N, Biaggini K, Dussaillant M, Roy M, Ogier-Denis E, Madi A, Jallane A, Feuilloley M, Hugot JP, Connil N, Barreau F. Pseudomonas fluorescens alters the intestinal barrier function by modulating il-1beta expression through hematopoietic nod2 signaling. Inflamm Bowel Dis 2015;21:543-55.

36. Brain O, Owens BM, Pichulik T, Allan P, Khatamzas E, Leslie A, Steevels T, Sharma S, Mayer A, Catuneanu AM, Morton V, Sun MY, Jewell D, Coccia M, Harrison O, Maloy K, Schonefeldt S, Bornschein S, Liston A, Simmons A. The intracellular sensor nod2 induces microrna-29 expression in human dendritic cells to limit il-23 release. Immunity 2013;39:521-36.

37. Amit-Romach E, Reifen R, Uni Z. Mucosal function in rat jejunum and ileum is altered by induction of colitis. Int J Mol Med 2006;18:721-7.

38. Strober W, Fuss IJ. Proinflammatory cytokines in the pathogenesis of inflammatory bowel diseases. Gastroenterology 2011;140:1756-67.

39. Brown GR, Lindberg G, Meddings J, Silva M, Beutler B, Thiele D. Tumor necrosis factor inhibitor ameliorates murine intestinal graft-versus-host disease. Gastroenterology 1999;116:593-601.

40. Leung Y, Geddes M, Storek J, Panaccione R, Beck PL. Hematopoietic cell transplantation for crohn's disease; is it time? World J Gastroenterol 2006;12:6665-73.

41. Rosenstiel P, Fantini M, Brautigam K, Kuhbacher T, Waetzig GH, Seegert D, Schreiber S. Tnf-alpha and ifn-gamma regulate the expression of the nod2 (card15) gene in human intestinal epithelial cells. Gastroenterology 2003;124:1001-9.

42. Robertson SJ, Zhou JY, Geddes K, Rubino SJ, Cho JH, Girardin SE, Philpott DJ. Nod1 and nod2 signaling does not alter the composition of intestinal bacterial communities at homeostasis. Gut Microbes 2013;4:222-31.

43. Daniel C, Sartory N, Zahn N, Geisslinger G, Radeke HH, Stein JM. Fty720 ameliorates th1-mediated colitis in mice by directly affecting the functional activity of cd4+cd25+ regulatory t cells. J Immunol 2007;178:2458-68.

44. Wallace JL, Keenan CM. An orally active inhibitor of leukotriene synthesis accelerates healing in a rat model of colitis. Am J Physiol 1990;258:G527-34. 
45. Neurath MF, Fuss I, Kelsall BL, Stuber E, Strober W. Antibodies to interleukin 12 abrogate established experimental colitis in mice. J Exp Med 1995;182:1281-90.

46. Meinzer U, Barreau F, Esmiol-Welterlin S, Jung C, Villard C, Leger T, Ben-Mkaddem S, Berrebi D, Dussaillant M, Alnabhani Z, Roy M, Bonacorsi S, Wolf-Watz H, Perroy J, Ollendorff V, Hugot JP. Yersinia pseudotuberculosis effector yopj subverts the nod2/rick/tak1 pathway and activates caspase-1 to induce intestinal barrier dysfunction. Cell Host Microbe 2012;11:337-51.

\section{Figures legend.}

\section{Figure 1: NOD2 expression in increased in intestinal mucosa of Crohn disease patients.}

$(A-F)$ Biopsies from controls $(A$ and $D)$ and naïve pediatric CD patients $(B, C, E$ and $F)$ were immunostained with anti-NOD2 antibodies. Ileal (A-C) or cecal (D-F) biopsies were obtained from inflamed $(C$ and $F)$ or uninflamed areas $(B$ and $E)$. Data shown are representative of 5 controls and $17 \mathrm{CD}$ patients. $(G)$ Number of NOD2 mRNA copies were normalized by the expression of Abelson gene and expressed as arbitrary units. mRNA levels were calculated for the epithelial monolayer (in blue) and the lamina propria (in red) from the same biopsy after laser microdissection. Biopsies were obtained from inflamed or uninflamed intestinal areas and referenced by an arbitrary number.

\section{Figure 2: Remote gut barrier dysfunctions of the small intestine are mediated by recirculating $\mathrm{CD}^{+} \mathrm{T}$-cells.}

$(A-L)$ C57BL/6 wild-type mice (Nod2 ${ }^{\mathrm{WT}}$ ) were instilled intra-rectally with TNBS. Vehicle control group was challenged by PBS-Ethanol. Mice were treated with anti-CD4 ${ }^{+}$antibodies or FTY720, an inhibitor of T-cell recirculation where indicated. 3 days after the instillation, the intensity of the colitis was monitored with the following parameters: $(A)$ Weight loss; $(B)$ Disease activity index; $(C)$ Colonic length $(\mathrm{cm})$; $(D)$ Colonic macroscopic score (Wallace score); (E) Pro-inflammatory cytokine levels in inflamed colon. In parallel, the duodenum and ileum were explored by microscopic examination after $(\mathrm{F})$ hematoxylin-eosin staining and $(\mathrm{G})$ Myeloperoxidase (MPO) immunostaining (colonic MPO expression in a mouse treated with DSS $3 \%$ for 7 days is shown as a positive inflammatory control); H) Protein levels of proinflammatory cytokines; (I) mRNA expressions of pro-inflammatory cytokines, Mlyk and Nod2; (J) levels of $\mathrm{CD} 4^{+}$T-cells in ileal Peyer's patches after $\mathrm{CD}^{+}$depletion with anti-CD4 ${ }^{+}$ antibodies; (K-L) Paracellular permeability assessed by Ussing chamber experiments. Original magnification, X20. Scale bars: $100 \mu \mathrm{M}$. (Each point $=$ one mice $;$ mean \pm s.e.m; 3 independent experiments; ${ }^{*} \mathrm{P}<0.05,{ }^{*} \mathrm{P}<0.01$ and ${ }^{* * *} \mathrm{P}<0.001$ vs. vehicle control group or indicated group; ${ }^{++} \mathrm{P}<0.01$ vs. TNBS group). 
Figure 3: CD4 and CD163 immunostaining of ileal and colonic biopsies from CD patients.

$(A-B)$ Ileal and $(C-D)$ colonic biopsies were collected from uninflamed or inflamed locations in $\mathrm{CD}$ patients. $(A$ and $C$ ) Grading of the inflammation was confirmed by coloration by hematoxylin-eosin (HES) and $\mathrm{CD}^{+}$or $\mathrm{CD} 163^{+}$positive cells were assessed by immunostaining. ( $B$ and $D$ ) $\mathrm{CD}^{+}$or $\mathrm{CD} 163^{+}$positive cells were counted in the lamina propria. (At least $\mathrm{n}=6$ fields per patients; mean $\pm \mathrm{SEM} ; * \mathrm{P}<0.05$ vs. uninflamed $\mathrm{CD} 4{ }^{+} \mathrm{T}$-cells; ${ }^{+} \mathrm{P}<0.05$ and ${ }^{+++} \mathrm{P}<0.001$ vs. uninflamed $\mathrm{CD} 163^{+} \mathrm{T}$-cells). Areas with lymphoid follicles were excluded.

Figure 4: Inhibition of MLCK prevents the small bowel alteration triggered by TNBS induced colitis.

$(A-M)$ Colitis was induced by intra-rectal administration of TNBS in (A-H) wild-type (WT) mice or (I-M) long isoform MLCK knock-out $\left(\mathrm{MLCK}^{\mathrm{KO}}\right)$ mice while the control group was challenged with PBS-Ethanol. Mice were treated with ML-7, an MLCK inhibitor, or PBS (Vehicle) where indicated. 3 days after induction of colitis, the following parameters were monitored to evaluate the severity of the colitis : $(A, I)$ Weight loss and $(B, J)$ Disease activity index; $(C, K)$ Colonic length; $(D, L)$ Wallace score; $(E)$ Levels of pro-inflammatory cytokine in inflamed colon. In parallel, the following parameters were measured in the duodenum and ileum: $(F)$ protein levels and; $(G)$ mRNA expression of pro-inflammatory cytokines, Mylk and Nod2; $(H, M)$ Paracellular permeability. (One point = one mouse; mean \pm s.e.m; 3 independent experiments; ${ }^{*} \mathrm{P}<0.05,{ }^{* *} \mathrm{P}<0.01$ and ${ }^{* * *} \mathrm{P}<0.001$ vs. vehicle control group or indicated group; ${ }^{++} \mathrm{P}<0.01$ vs. TNBS group; ns=non-significant $)$.

\section{Figure 5: NOD2 activation reverses the remote effects of TNBS-induced colitis.}

$(A-C)$ Localization of muramyl dipeptide (MDP) in the small intestine after intraperitoneal injection. Rhodamine-labeled MDP is detected in epithelial cells of the small intestine two hours after IP injection. Fluorescence (red) was detected in epithelial cells of the $(B)$ duodenum and $(C)$ ileum. Nuclei were stained with DAPI (blue). $(A)$ The ileum of a mouse injected with distilled water was used as a negative control. Original magnification, X40. Scale bars: $100 \mu \mathrm{M} .(D-K)$ C57BL/6 wild-type mice were instilled intra-rectally with TNBS. Vehicle control group was challenged with PBS-Ethanol. Mice were treated with MDP where indicated. 3 days after induction, the colitis was monitored by the following parameters: $(D)$ Disease activity index; $(E)$ Colonic length; $(F)$ Wallace score; $(G)$ levels of pro-inflammatory 
cytokines in inflamed colon; $(H)$ Weight loss. In parallel, the following measures were made in the duodenum and ileum: $(I)$ mRNA expression of pro-inflammatory cytokines, Mylk and Nod2; $(J)$ protein expression of pro-inflammatory cytokines; $(K)$ Paracellular permeability. (Each point $=$ one mouse; mean \pm s.e.m; 3 independent experiments; ${ }^{*} \mathrm{P}<0.05,{ }^{* *} \mathrm{P}<0.01$ and ${ }^{* * * *} \mathrm{P}<0.001$ vs. vehicle group or indicated group; ${ }^{+} \mathrm{P}<0.05,{ }^{++} \mathrm{P}<0.01$ and ${ }^{++} \mathrm{P}<0.001$ vs. TNBS vehicle group).

Figure 6: TNBS induced colitis leads to small bowel inflammation in Nod2 deficient or mutated mice.

$(A-F) \operatorname{Nod} 2^{\mathrm{WT}}, \operatorname{Nod} 2^{\mathrm{KO}}$ and $\operatorname{Nod} 2^{2939 \mathrm{ins}}$ mice were challenged by intra-rectal instillation of TNBS. 3 days after induction, the colitis was monitored with the following parameters: $(A)$ Weight loss; $(B)$ Disease activity index; $(C)$ Colonic length; $(D)$ Wallace score. In parallel, the duodenum and ileum were studied by: $(E$ and $F$ ) microscopic examination after hematoxylineosin staining; $(G)$ protein levels of pro-inflammatory cytokines. (One point = one mouse; mean \pm s.e.m; 3 independent experiments; ${ }^{* *} \mathrm{P}<0.01$ and ${ }^{* * *} \mathrm{P}<0.001$ vs. Vehicle group; ${ }^{++} \mathrm{P}<0.01$ vs. indicated group; ns=non-significant).

Figure 7: The small bowel is not protected by muramyl dipeptide in Nod2 deficient mice. The gut microbiota does not play a major role.

(A-E) $\operatorname{Nod} 2^{\mathrm{WT}}, \operatorname{Nod} 2^{\mathrm{KO}}$ and $\operatorname{Nod} 2^{2939 \mathrm{ins}}$ mice were challenged by intra-rectal instillation of TNBS. Mice were treated with muramyl dipeptide (MDP) or PBS (vehicle) where indicated. $(A)$ Disease activity index; $(B)$ Colonic length; $(C)$ Wallace score; Levels of pro-inflammatory cytokine in the (D) colon or (E) small bowel. (F) paracellular permeability in the small bowel. (G-I). $\operatorname{Nod} 2^{\mathrm{WT}}$ and $\operatorname{Nod} 2^{\mathrm{KO}}$ mice were left separated or co-housed for at least 6 weeks to homogenize their microbiota. 3 days after TNBS-colitis induction, the following parameters were monitored: (G) Colonic length; (H) Colonic macroscopic score (Wallace score) and; (I) ileal Paracellular permeability (One point $=$ one mouse; mean \pm s.e.m; 3 independent experiments; ${ }^{*} \mathrm{P}<0.05$ and ${ }^{* *} \mathrm{P}<0.01$ vs. indicated group; ${ }^{+} \mathrm{P}<0.05,{ }^{++} \mathrm{P}<0.05$ and ${ }^{+++} \mathrm{P}<0.001$ vs. instilled TNBS Nod2 ${ }^{\mathrm{WT}}$ group).

Figure 8: Both hematopoietic and non-hematopoietic Nod2 regulate the small bowel function remote from gut injury.

$(A-C)$ Chimeric mice were generated by transplantation of BMSC mice from Nod2 ${ }^{\mathrm{WT}}$ to 
$\mathrm{Nod} 2^{\mathrm{KO}}(\mathrm{WT} \rightarrow \mathrm{KO})$ or from Nod2 $2^{\mathrm{KO}}$ to $N o d 2^{\mathrm{WT}}(\mathrm{KO} \rightarrow \mathrm{WT})$. Mice transplanted with BMSC of the same genetic background $(\mathrm{WT} \rightarrow \mathrm{WT}$ or $\mathrm{KO} \rightarrow \mathrm{KO}$ ) served as controls. Where indicated $\mathrm{WT} \rightarrow \mathrm{KO}$ and $\mathrm{WT} \rightarrow \mathrm{WT}$ (respectively $\mathrm{KO} \rightarrow \mathrm{WT}$ and $\mathrm{KO} \rightarrow \mathrm{KO}$ ) were pooled and annotated $\mathrm{WT} \rightarrow \mathrm{WT} / \mathrm{KO}$ (respectively $\mathrm{KO} \rightarrow \mathrm{WT} / \mathrm{KO}$ ). Three months after bone marrow transplantation, chimerism for CD45 isoforms expression was monitored in Peyer's patches of chimeric mice via flow cytometry. (A) Percentages of CD45.1 and CD45.2 positive cells. $(B$ and $C)$ Percentages of $\mathrm{CD}^{+}, \mathrm{CD}^{+} 9^{+}$and $\mathrm{CD} 11 \mathrm{c}^{+}$cells in CD45Ly5.1 or CD45Ly5.2 respectively. $(D-K)$ Three month after transplantation, colitis was induced by intra-rectal administration of TNBS. Mice were treated with MDP or PBS (vehicle) where indicated. 3 days after induction of colitis, the following parameters were monitored: $(D)$ Weight loss; $(E)$ Disease activity index; $(F)$ Wallace score; $(G)$ colonic length; $(H)$ levels of pro-inflammatory cytokines in inflamed colon. In the ileum, the following parameters were recorded in parallel: (I) microscopic score; $(J)$ Levels of pro-inflammatory cytokines and; $(K)$ Paracellular permeability. (At least $n=6$ per group; mean \pm s.e.m; data show a combination of two independent experiments; ${ }^{*} \mathrm{P}<0.05,{ }^{* *} \mathrm{P}<0.01$ and ${ }^{* * *} \mathrm{P}<0.001$ vs. indicated group; ${ }^{+} \mathrm{P}<0.05$, ${ }^{++} \mathrm{P}<0.01$ and ${ }^{+++} \mathrm{P}<0.001$ vs. instilled TNBS control group; ns=non-significant). 
bioRxiv preprint first posted online Jan. 3, 2019; doi: http://dx.doi.org/10.1101/510933. The copyright holder for this preprint (which was not peer-reviewed) is the author/funder, who has granted bioRxiv a license to display the preprint in perpetuity. It is made available under a CC-BY-NC-ND 4.0 International license.

Table 1. List of primers used for qPCR analyses in mice.

\begin{tabular}{|c|c|c|}
\hline mRNA & Sense & Antisense \\
\hline long MLCK isoform & 5'-ACATGCTACTGAGTGGCCTCTCT-3' & 5'GGCAGACAGGACATTGTTTAAGG-3' \\
\hline IL- $1 \beta$ & 5'-CAACCAACAAGTGATATTCTCCATG-3' & 5'- GATCCACACTCTCCAGCTGCA-3' \\
\hline IL-12 & 5'-ACGAGAGTTGCCTGGCTACTAG-3' & 5'-CCTCATAGATGCTACCAAGGCAC-3' \\
\hline IFN- $\gamma$ & 5'-CAGCAACAGCAAGGCGAAAAAGG-3' & 5'-TTTCCGCTTCCTGAGGCTGGAT-3' \\
\hline TNF- $\alpha$ & 5'-CATCTTCTCAAAATTCGAGTGACAA-3' & 5'-TGGGAGTAGACAAGGTACAACCC-3' \\
\hline Nod2 & 5'-GCCAGTACGAGTGTGAGGAG -3' & 5'-CCCTGACGTGCTGTAGAAGG-3' \\
\hline
\end{tabular}




\section{Controls}
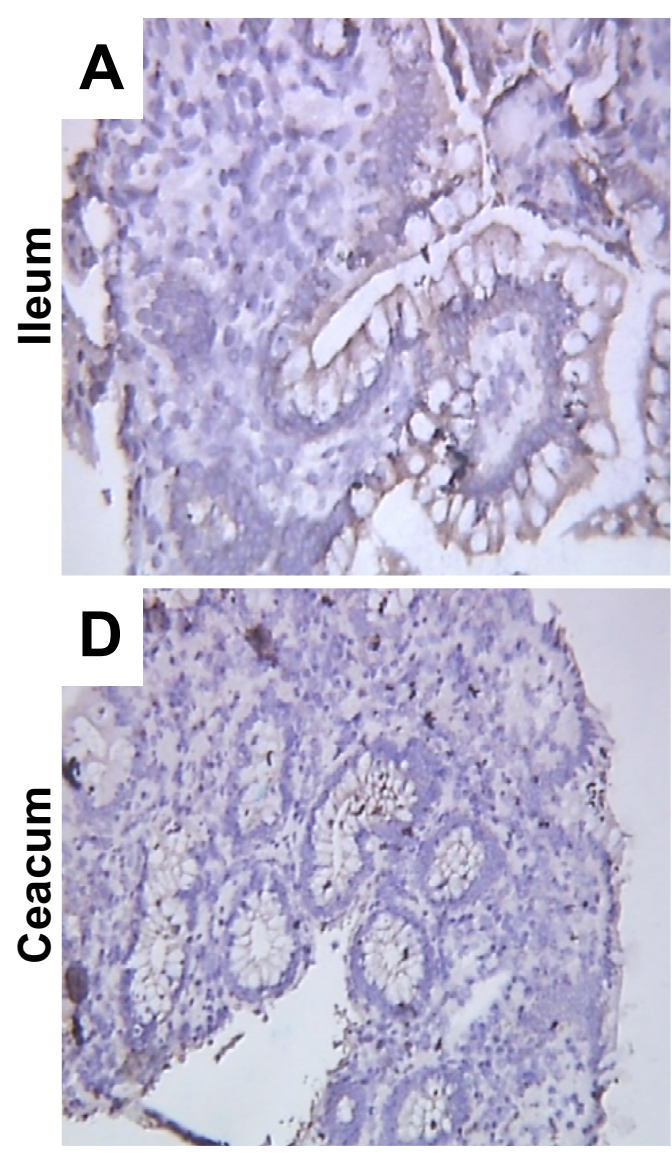

CD patients
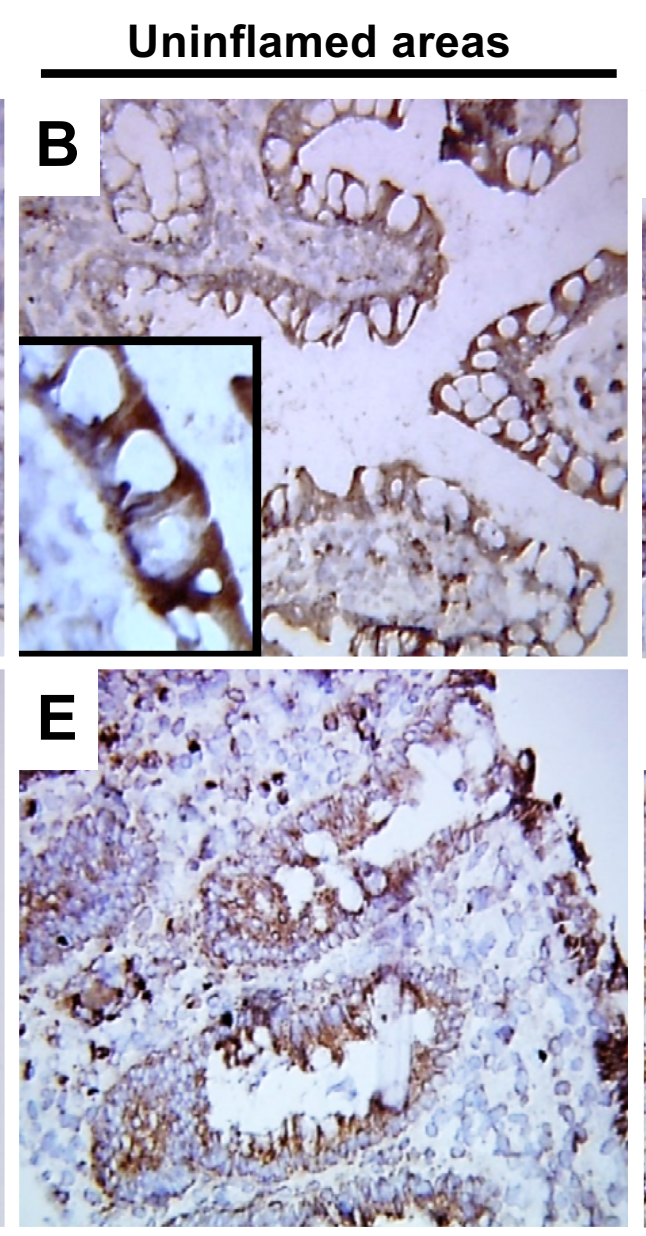

\section{Inflamed areas}
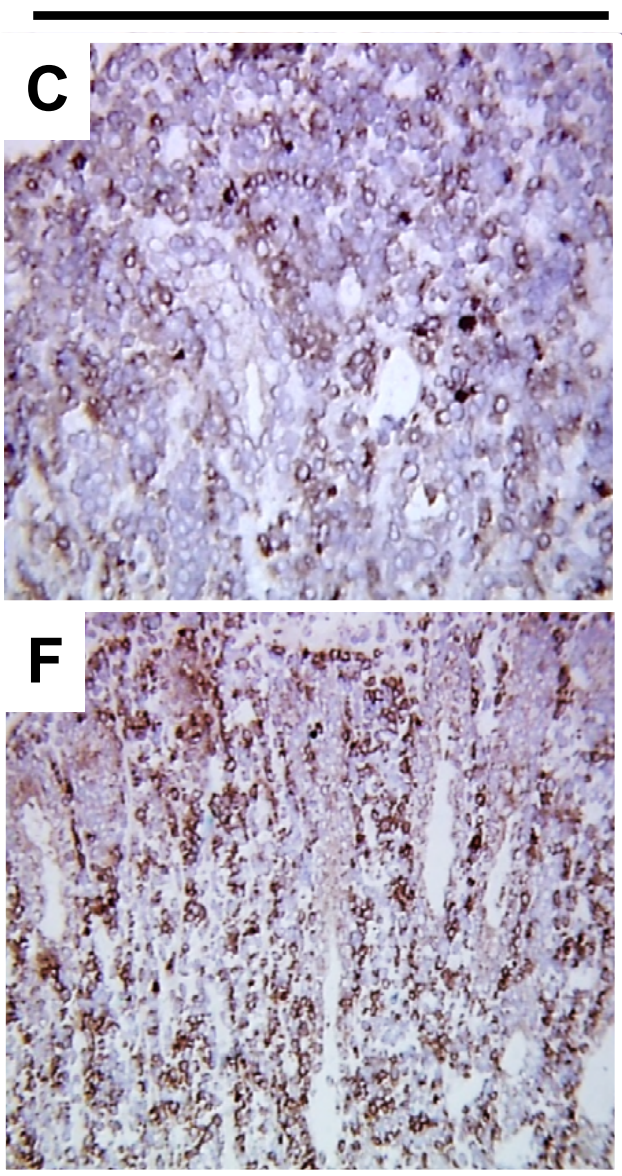

G

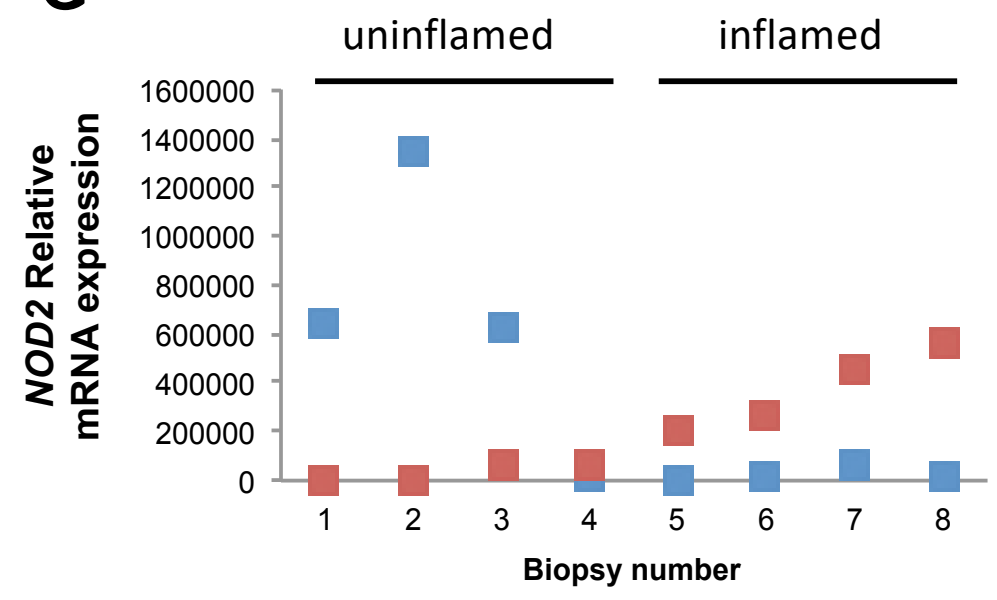

Epithelial Layer

Lamina propria 


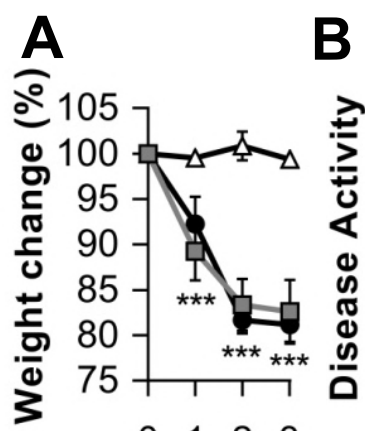

$\begin{array}{llll}0 & 1 & 2 & 3\end{array}$

Time (days)

E

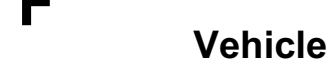

도ำ

Vehicle

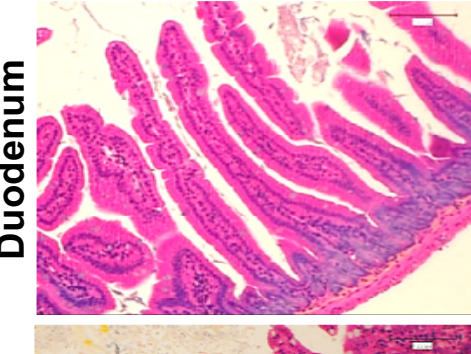

$\underline{\underline{\Xi}}$

H

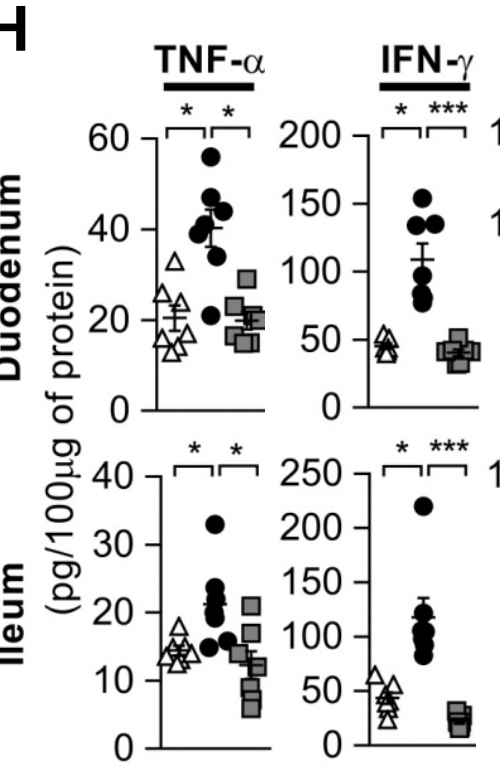

$J$

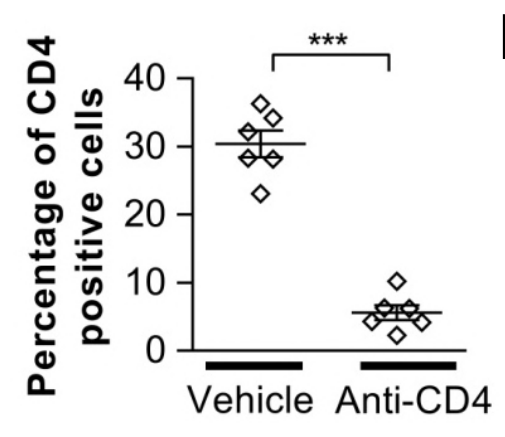

C D

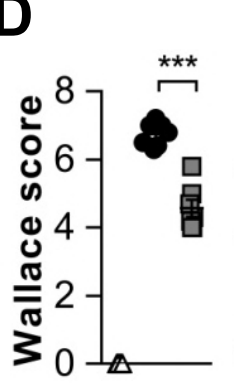

$0 \begin{array}{lllll}0 & 1 & 2 & 3\end{array}$

Time (days)

$\mathbf{E}$

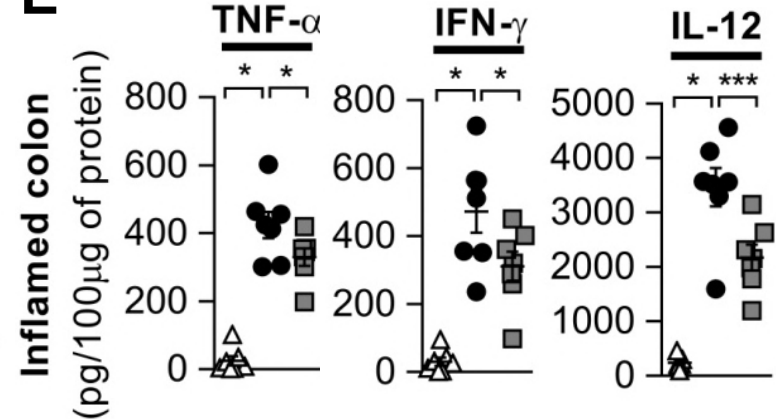

G

TNBS
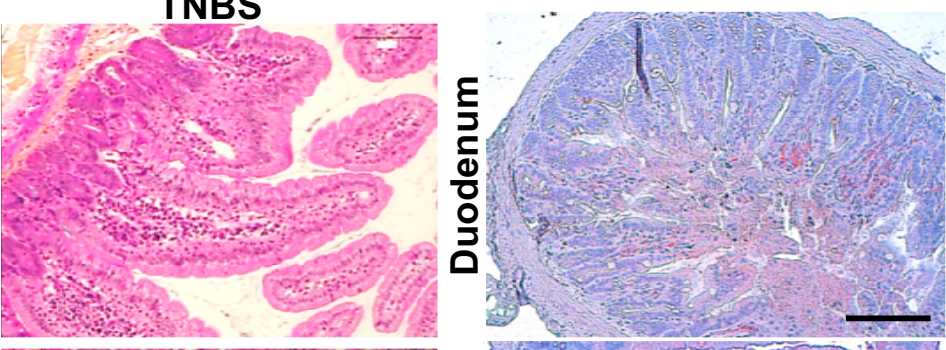

$\Delta$ Vehicle

- TNBS + Vehicle

- TNBS + anti-CD4+

\section{Inflamed colon}

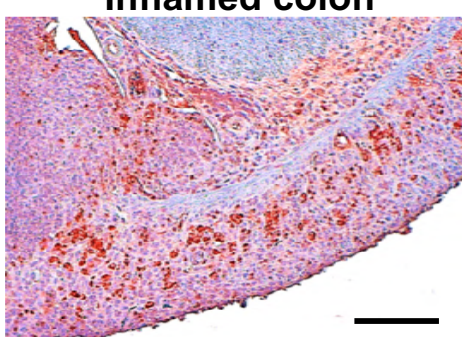

2
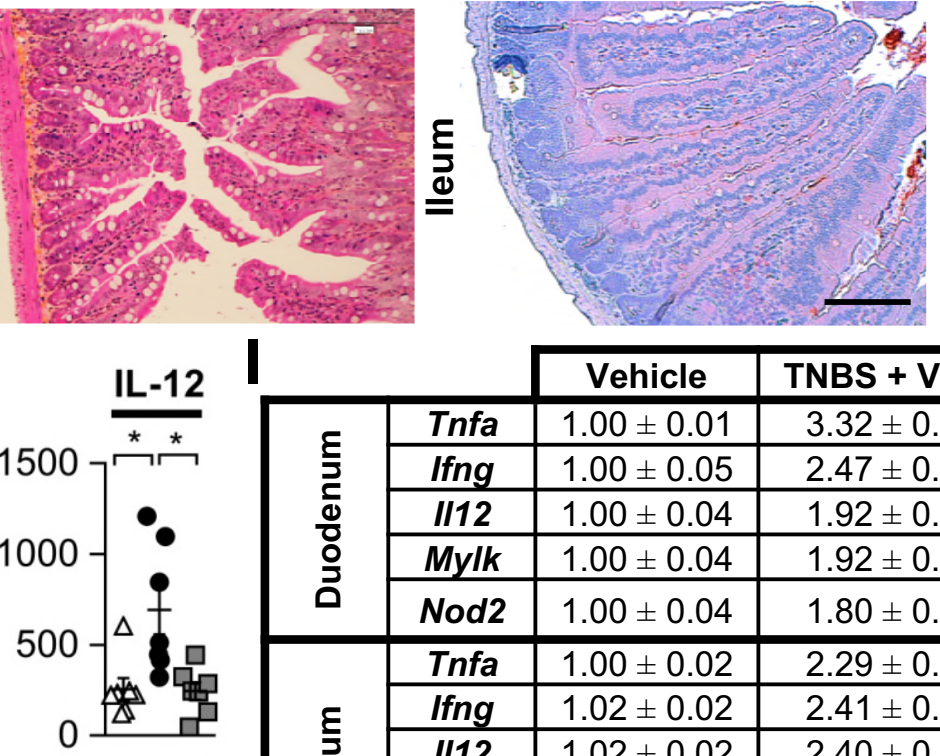

\begin{tabular}{|c|c|c|c|c|}
\hline \multirow{5}{*}{ 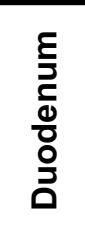 } & Tnfa & $1.00 \pm 0.01$ & $3.32 \pm 0.28$ ** & $2.05 \pm 0.21++$ \\
\hline & Ifng & $1.00 \pm 0.05$ & $2.47 \pm 0.32$ ** & $1.35 \pm 0.18+$ \\
\hline & II12 & $1.00 \pm 0.04$ & $1.92 \pm 0.20$ ** & $1.04 \pm 0.04+$ \\
\hline & Mylk & $1.00 \pm 0.04$ & $1.92 \pm 0.08^{* *}$ & $1.23 \pm 0.12++$ \\
\hline & Nod2 & $1.00 \pm 0.04$ & $1.80 \pm 0.07 * *$ & $1.12 \pm 0.04+$ \\
\hline \multirow{5}{*}{$\stackrel{\underline{\xi}}{\underline{\underline{\sigma}}}$} & Tnfa & $1.00 \pm 0.02$ & $2.29 \pm 0.36$ ** & $1.32 \pm 0.14+$ \\
\hline & Ifng & $1.02 \pm 0.02$ & $2.41 \pm 0.39$ ** & $1.48 \pm 0.17+$ \\
\hline & 1112 & $1.02 \pm 0.02$ & $2.40 \pm 0.24$ ** & $1.29 \pm 0.15+$ \\
\hline & Mylk & $1.00 \pm 0.04$ & $1.98 \pm 0.26$ ** & $1.20 \pm 0.08++$ \\
\hline & Nod2 & $1.00 \pm 0.04$ & $1.91 \pm 0.22$ ** & $1.19 \pm 0.13+$ \\
\hline \multirow{5}{*}{ 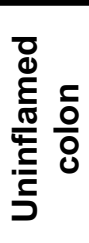 } & Tnfa & $1.00 \pm 0.03$ & $1.84 \pm 0.12^{* *}$ & $1.30 \pm 0.12+$ \\
\hline & Ifng & $1.00 \pm 0.03$ & $3.06 \pm 0.20^{* * *}$ & $1.25 \pm 0.12++$ \\
\hline & II12 & $1.00 \pm 0.03$ & $3.26 \pm 0.10$ *** & $1.25 \pm 0.22++$ \\
\hline & Mylk & $1.02 \pm 0.02$ & $2.00 \pm 0.14^{* * *}$ & $1.30 \pm 0.05+$ \\
\hline & Nod2 & $1.00 \pm 0.03$ & $1.74 \pm 0.12 * *$ & $1.30 \pm 0.12+$ \\
\hline
\end{tabular}

$\mathrm{K}$
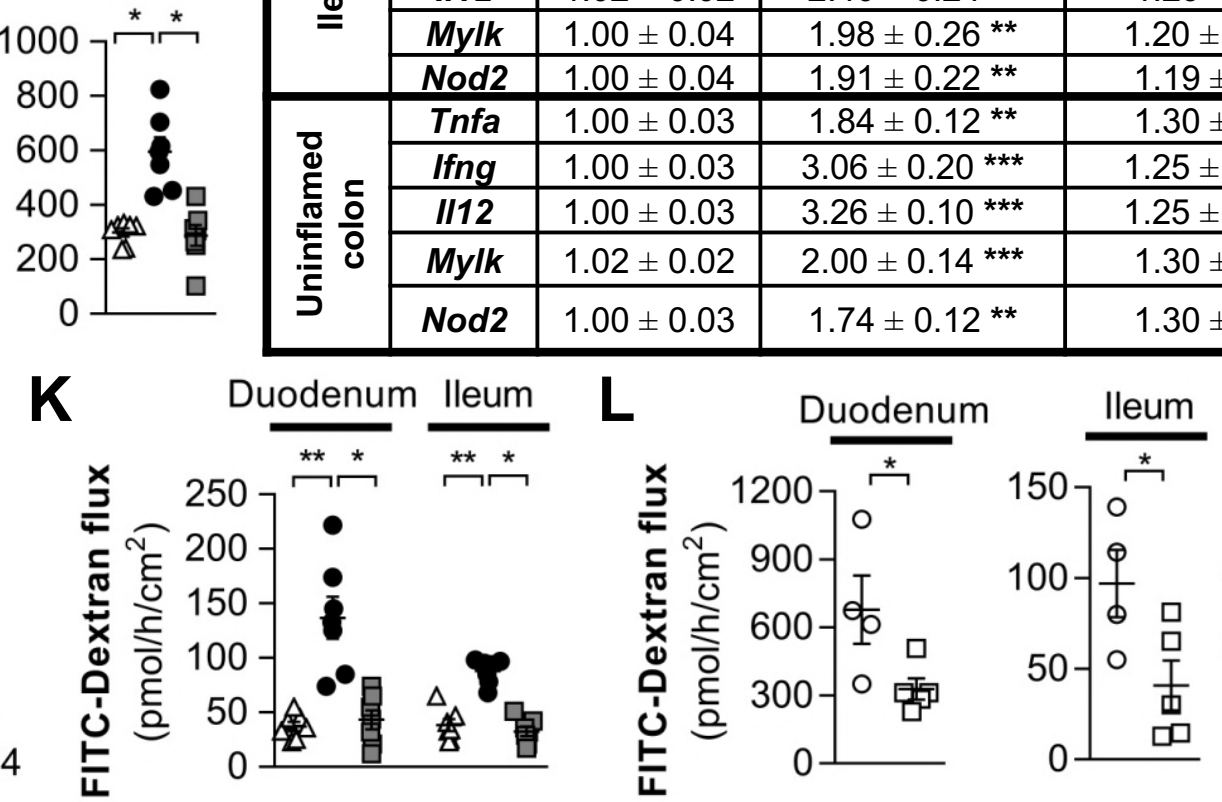

o Vehicle

口 FTY 720 
bioRxiv preprint first posted online Jan. 3, 2019; doi: http://dx.doi.org/10.1101/510933. The copyright holder for this preprint (which was not peer-reviewed) is the author/funder, who has granted bioRxiv a license to display the preprint in perpetuity.

It is made available under a CC-BY-NC-ND 4.0 International license.

A

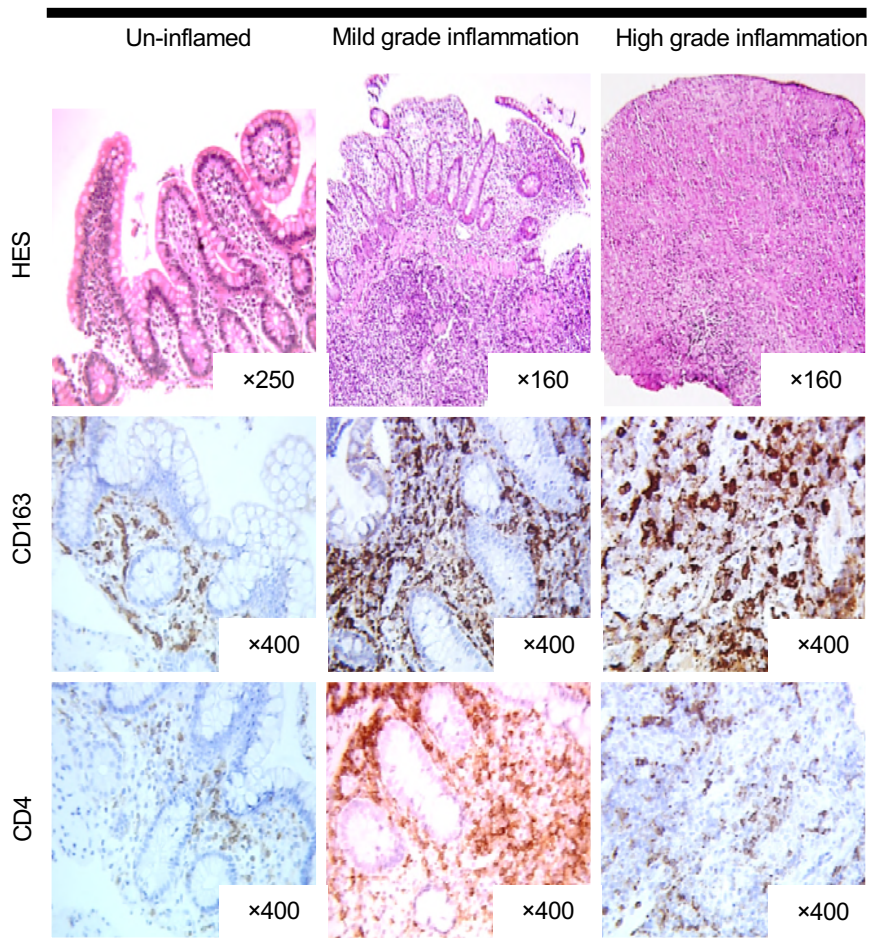

B

lleum

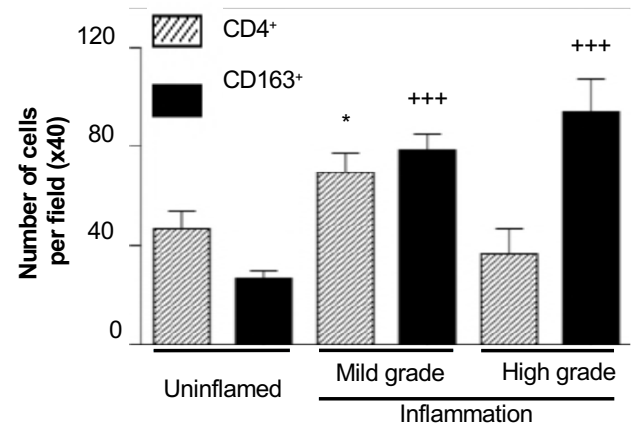

C Colon
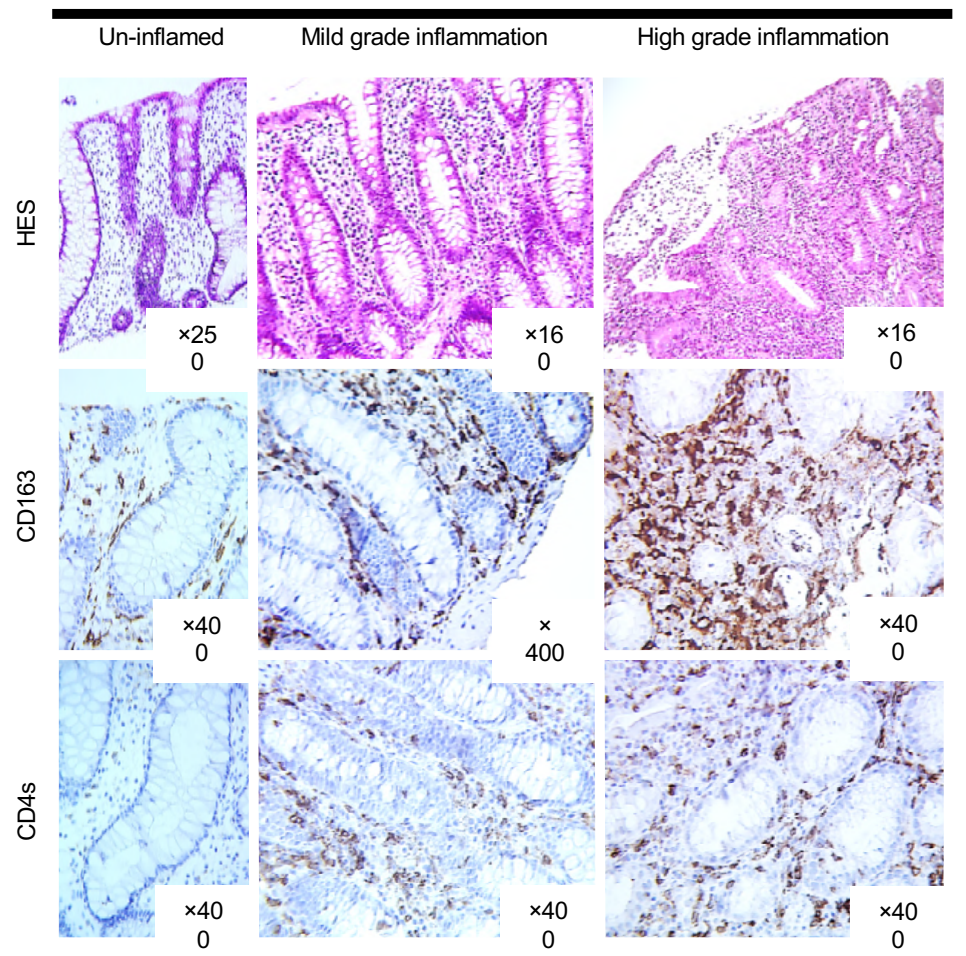

D

Colon

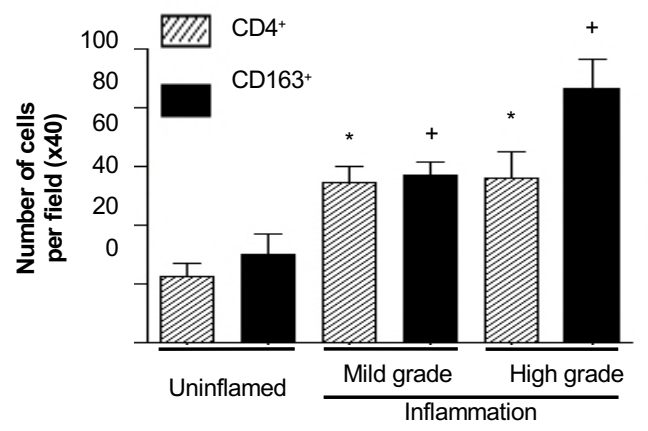



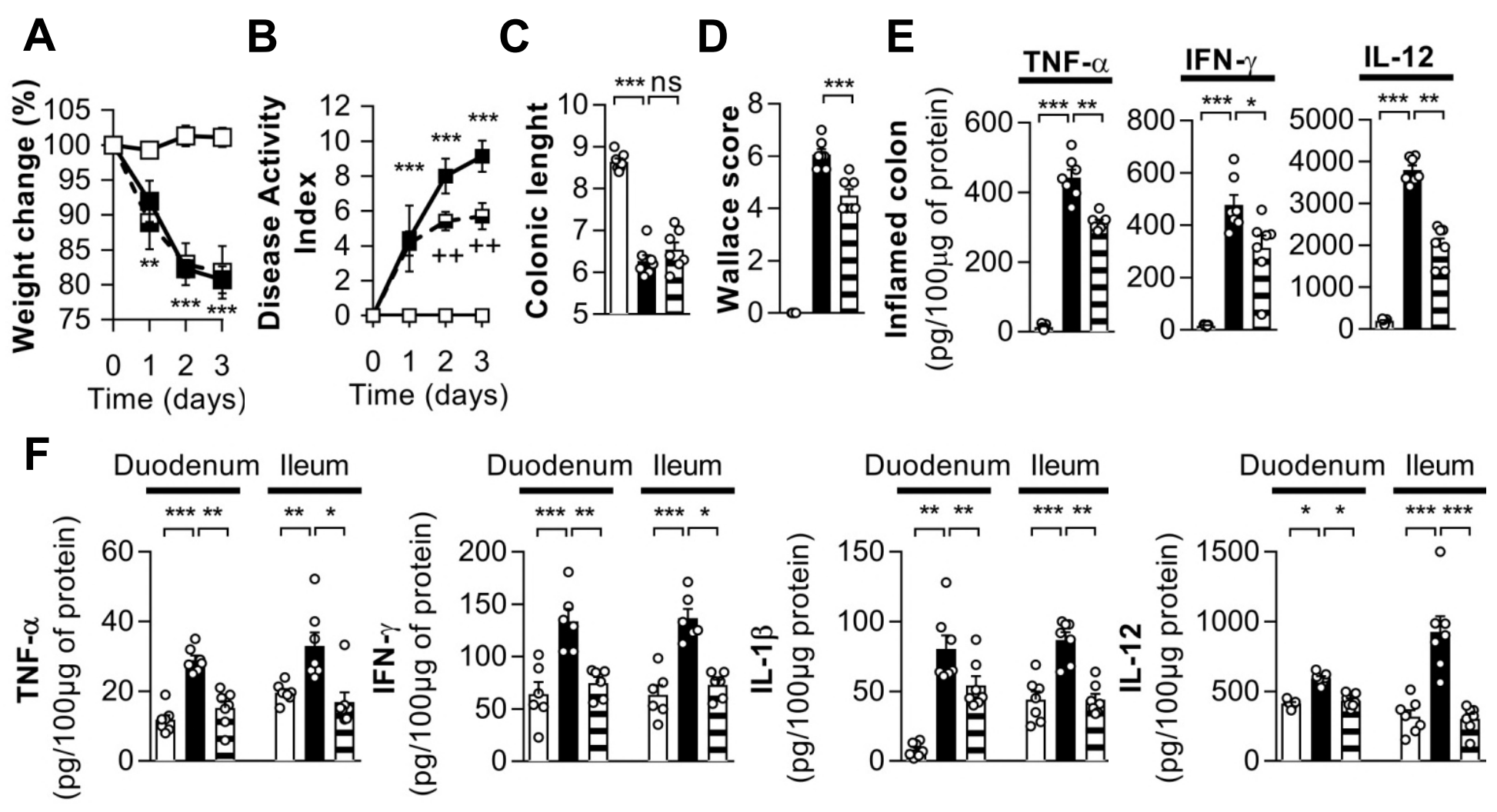

\begin{tabular}{|c|c|c|c|c|}
\hline & & Vehicle & TNBS + Vehicle & TNBS + ML-7 \\
\hline \multirow{6}{*}{ 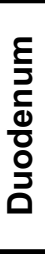 } & Tnfa & $1.04 \pm 0.03$ & $2.86 \pm 0.28$ *** & $1.82 \pm 0.26++$ \\
\hline & Ifng & $1.01 \pm 0.06$ & $2.13 \pm 0.12^{* *}$ & $0.99 \pm 0.02++$ \\
\hline & $I 11 b$ & $1.00 \pm 0.05$ & $2.77 \pm 0.10^{* * *}$ & $1.54 \pm 0.10++$ \\
\hline & II12 & $1.02 \pm 0.03$ & $1.74 \pm 0.12^{*}$ & $1.35 \pm 0.12$ \\
\hline & Mylk & $1.00 \pm 0.04$ & $1.84 \pm 0.14^{* *}$ & $1.32 \pm 0.11+$ \\
\hline & Nod2 & $1.00 \pm 0.10$ & $1.92 \pm 0.09$ ** & $1.07 \pm 0.05++$ \\
\hline \multirow{6}{*}{ 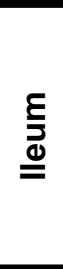 } & Tnfa & $1.00 \pm 0.17$ & $3.13 \pm 0.21^{* * *}$ & $2.06 \pm 0.10++$ \\
\hline & Ifng & $1.01 \pm 0.02$ & $2.64 \pm 0.20$ ** & $1.41 \pm 0.10+$ \\
\hline & II1b & $1.00 \pm 0.06$ & $2.66 \pm 0.20$ *** & $1.90 \pm 0.10++$ \\
\hline & II12 & $1.01 \pm 0.02$ & $2.66 \pm 0.20^{* *}$ & $1.12 \pm 0.06++$ \\
\hline & Mylk & $1.02 \pm 0.06$ & $2.18 \pm 0.23^{* *}$ & $1.40 \pm 0.08+$ \\
\hline & Nod2 & $1.01 \pm 0.04$ & $2.03 \pm 0.22 * * *$ & $1.14 \pm 0.09++$ \\
\hline
\end{tabular}

H
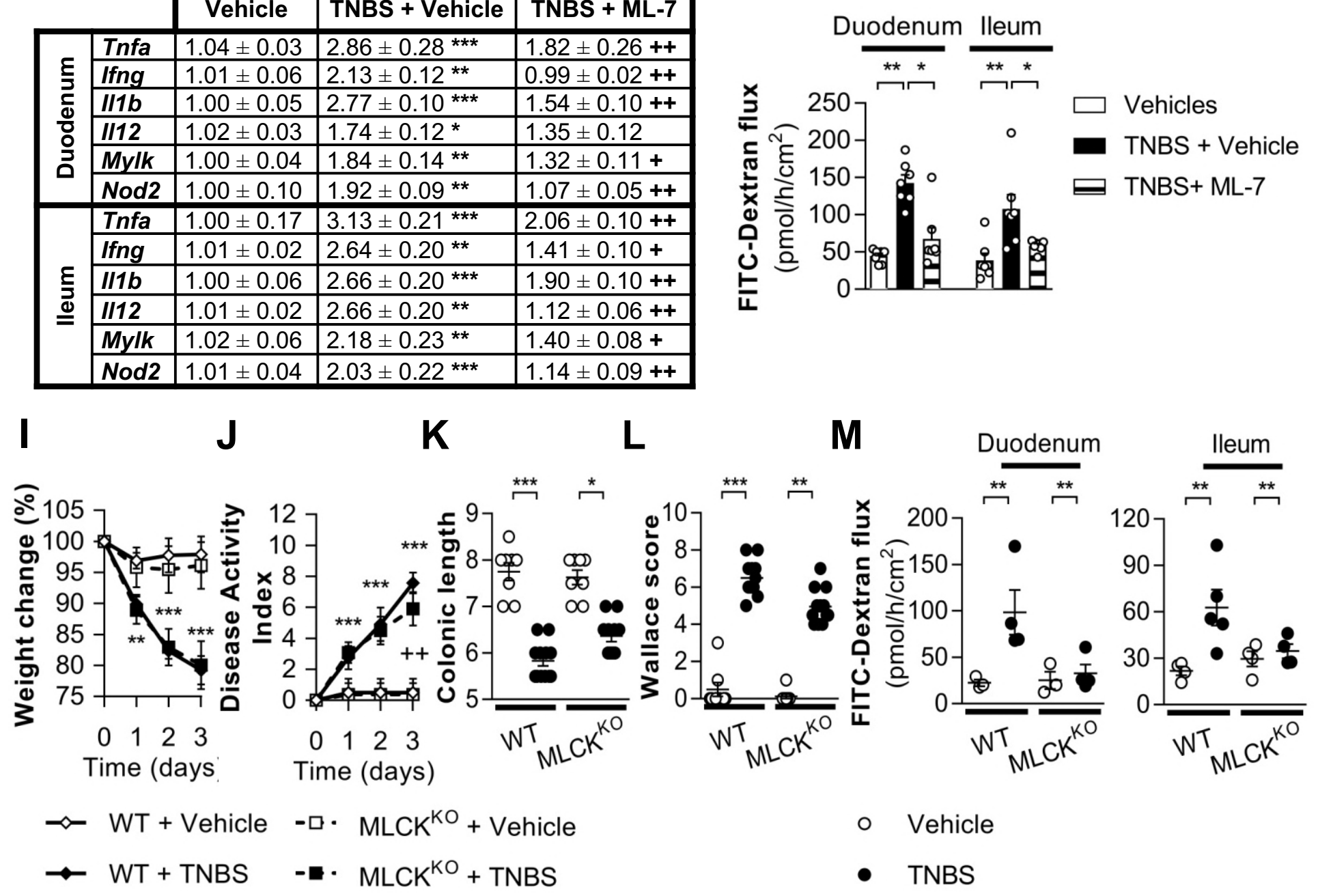

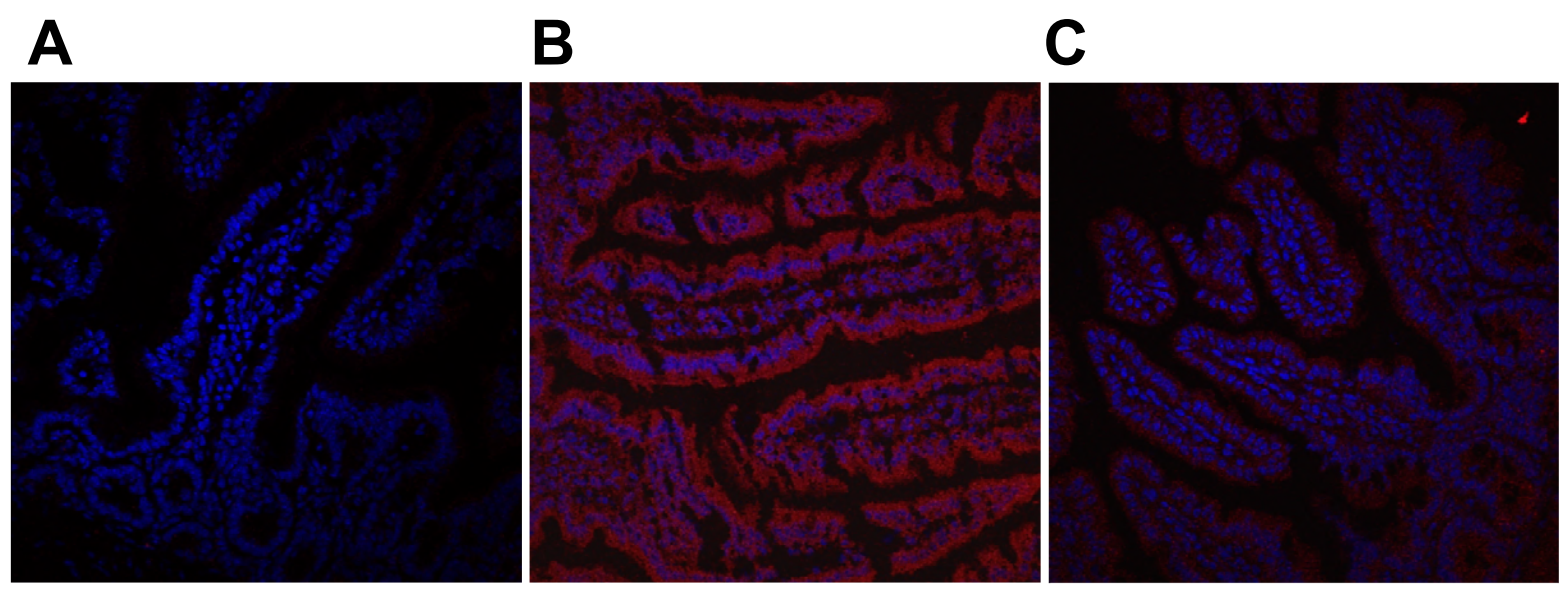

D

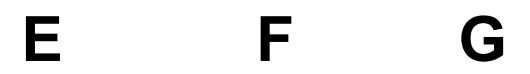

H
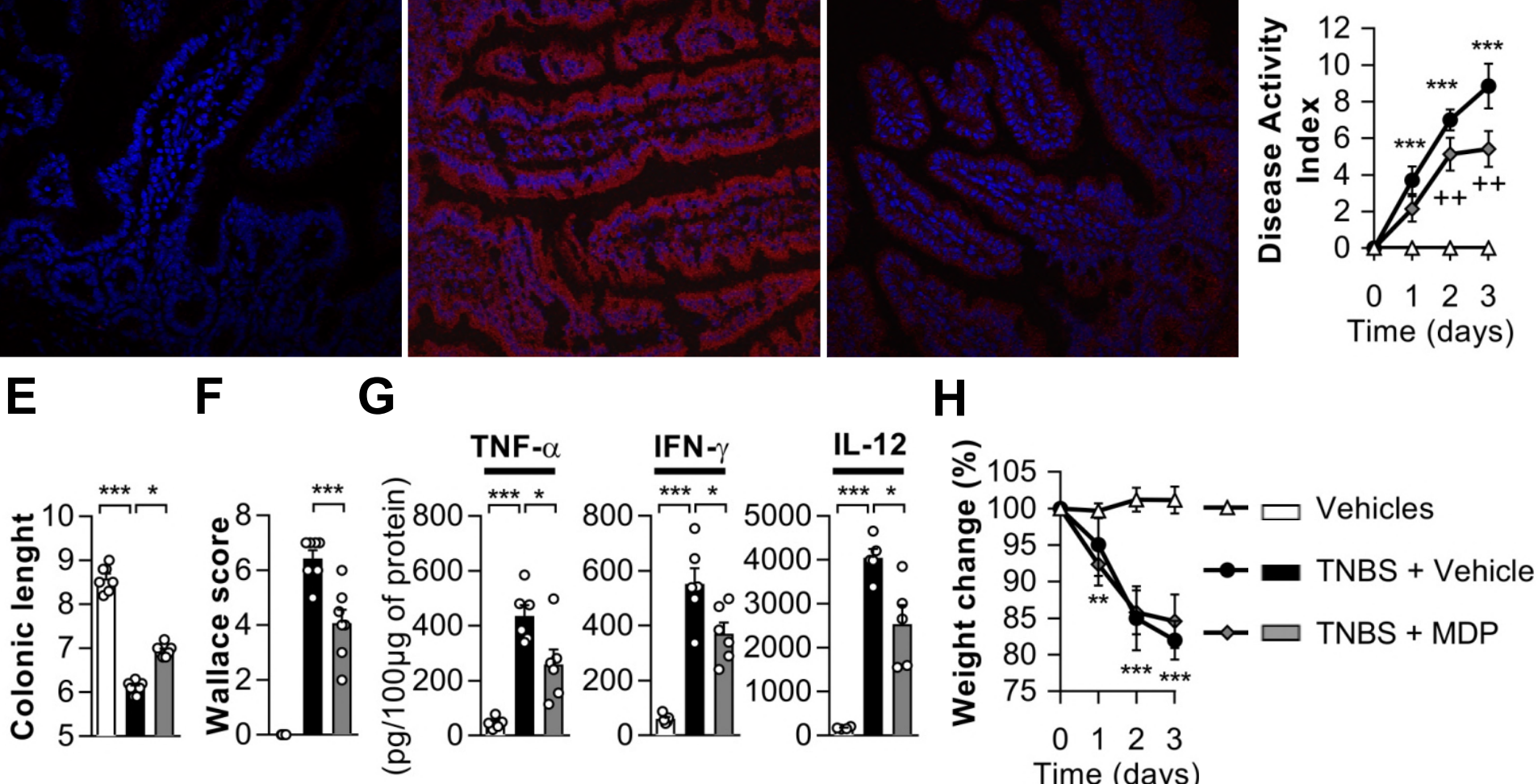

$\begin{array}{llll}0 & 1 & 2 & 3\end{array}$

Time (days)

\begin{tabular}{|l|c|l|l|l|l|l|}
\cline { 2 - 7 } \multicolumn{1}{c|}{} & \multicolumn{3}{c|}{ Duodenum } & \multicolumn{3}{c|}{ Ileum } \\
\cline { 2 - 7 } \multicolumn{1}{c|}{} & Vehicles & TNBS + Vehicle & TNBS + MDP & Vehicles & TNBS + Vehicle & TNBS + MDP \\
\hline Tnfa & $1.00 \pm 0.05$ & $3.29 \pm 0.07^{* * *}$ & $1.57 \pm 0.13++$ & $1.00 \pm 0.04$ & $2.61 \pm 0.28^{* * *}$ & $1.55 \pm 0.13+$ \\
\hline Ifng & $1.01 \pm 0.04$ & $3.39 \pm 0.18^{* *}$ & $1.56 \pm 0.13++$ & $1.01 \pm 0.04$ & $2.90 \pm 0.34 * *$ & $2.04 \pm 0.18+$ \\
\hline II12 & $1.00 \pm 0.02$ & $2.15 \pm 0.16^{* *}$ & $1.33 \pm 0.07+$ & $1.00 \pm 0.02$ & $2.34 \pm 0.28^{* *}$ & $1.25 \pm 0.06+$ \\
\hline Nod2 & $1.00 \pm 0.08$ & $1.67 \pm 0.14^{*}$ & $1.49 \pm 0.15$ & $1.00 \pm 0.07$ & $1.60 \pm 0.2 *^{*}$ & $1.69 \pm 0.22$ \\
\hline
\end{tabular}

$\mathbf{J}$

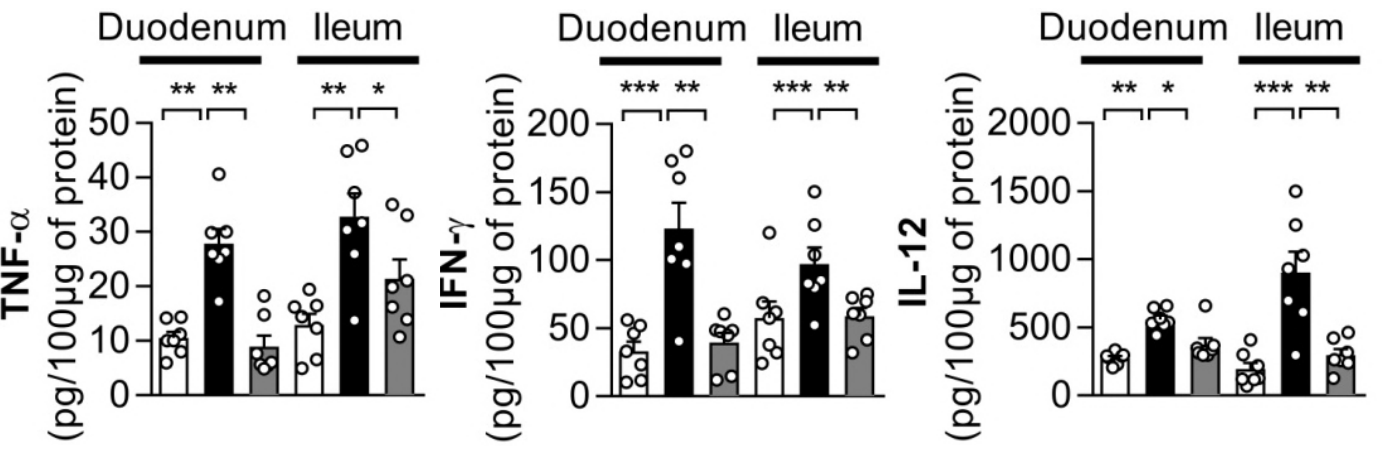

K

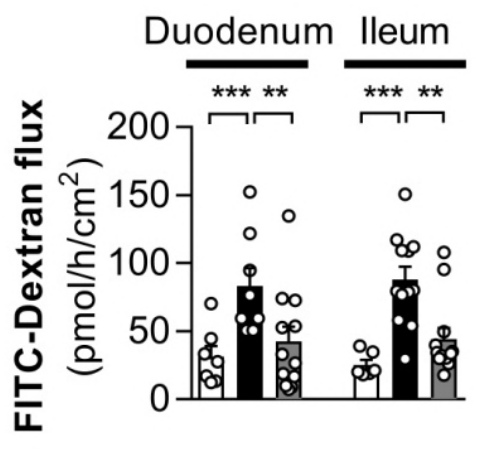




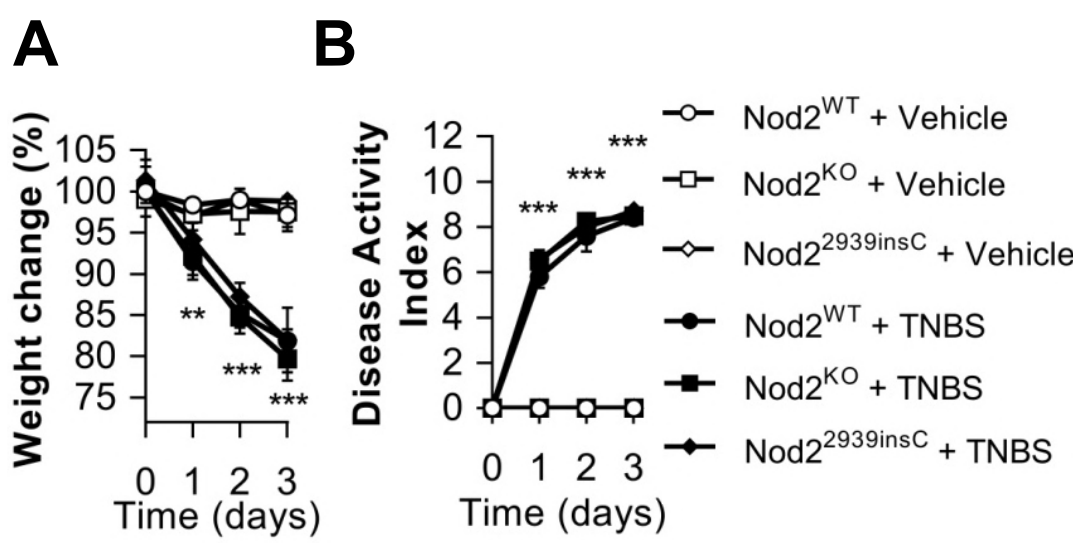

$\mathbf{E}$

ํㅗㅇ

\section{Duodenum}
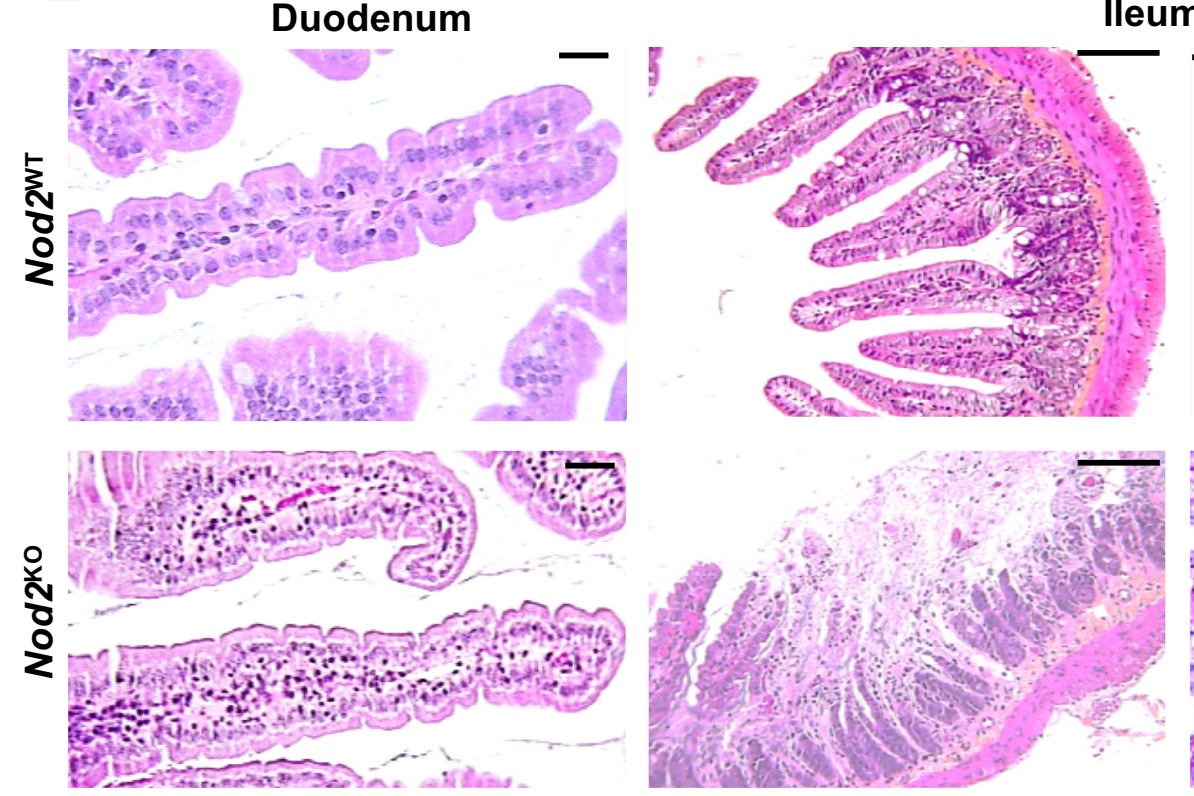

lleum
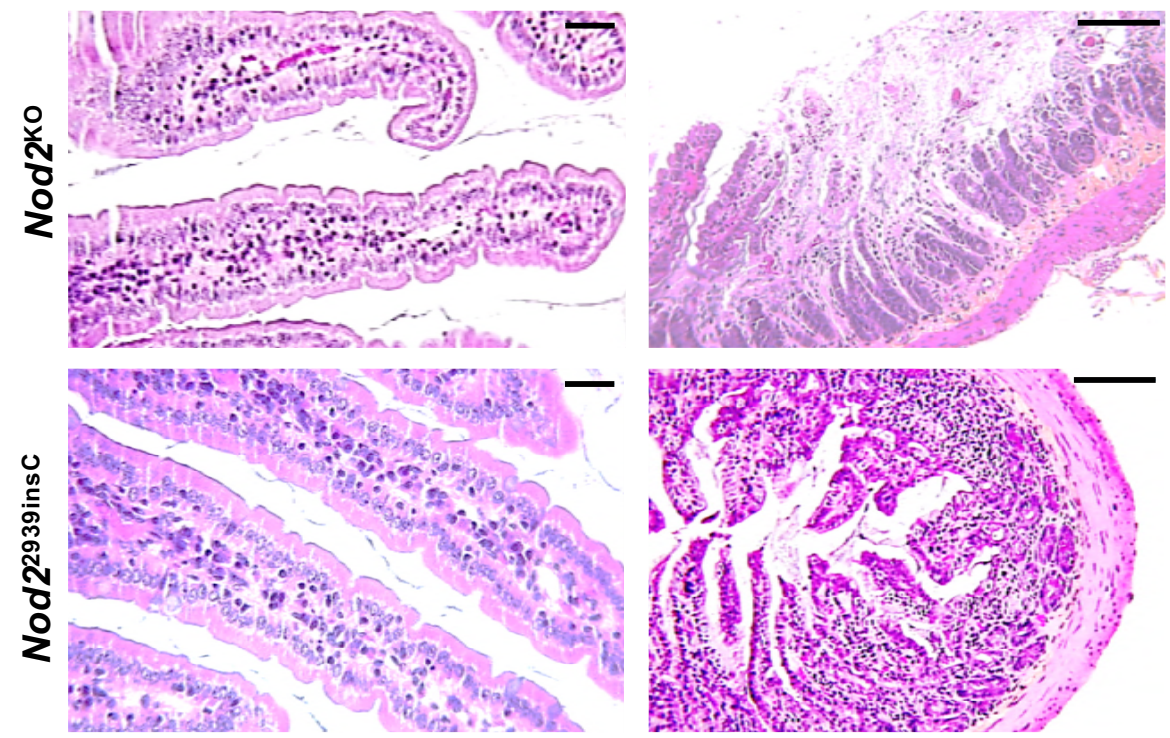

G

TNF- $\alpha$
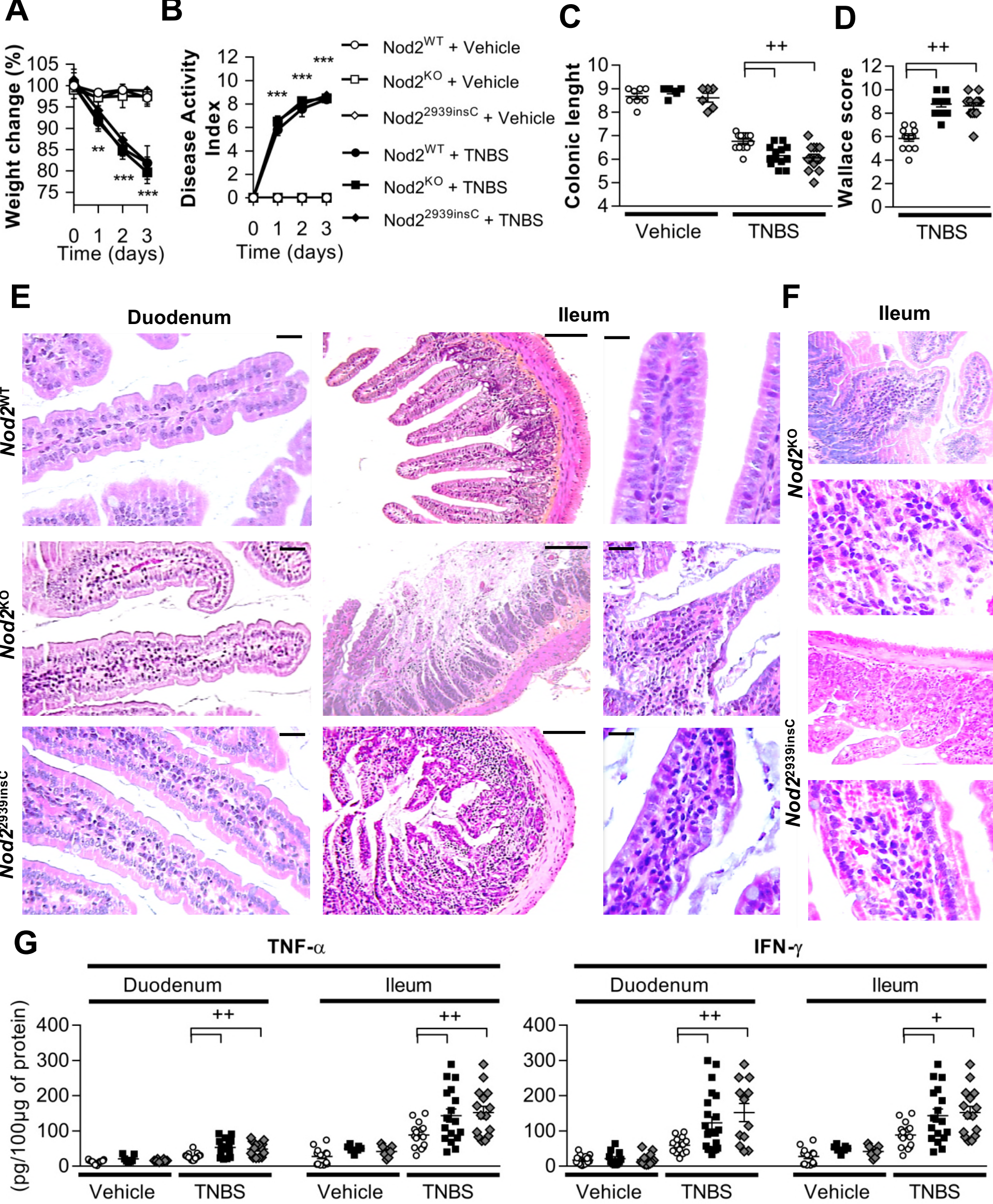

D

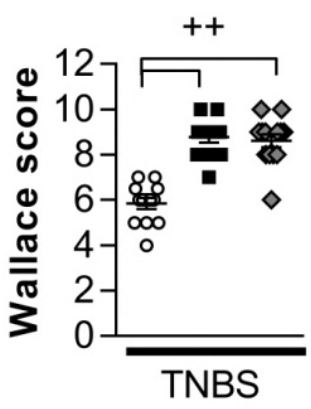

F
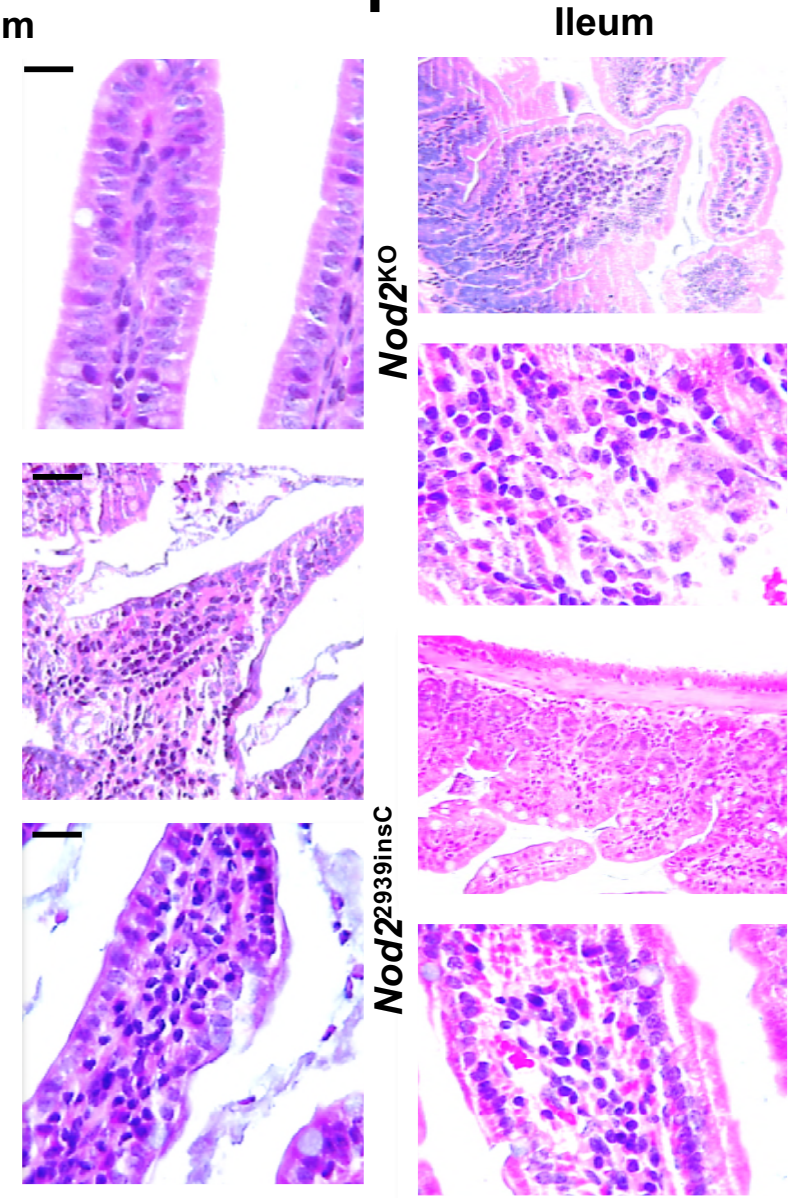

IFN- $\gamma$
O Nod2 ${ }^{\text {WT }}$

$\mathrm{Nod} 2^{\mathrm{KO}}$ 

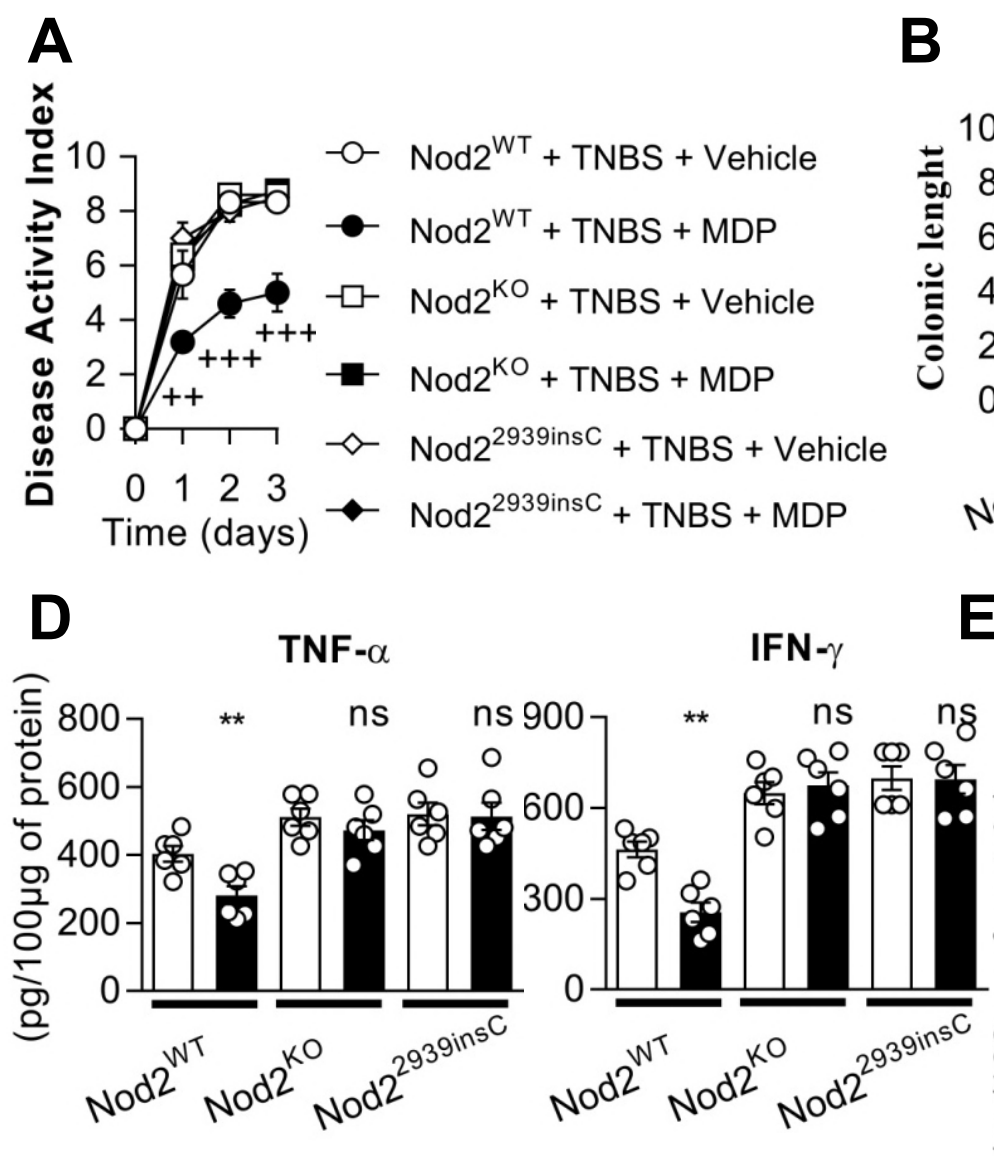

$\mathbf{F}$

FITC-Dextran flux
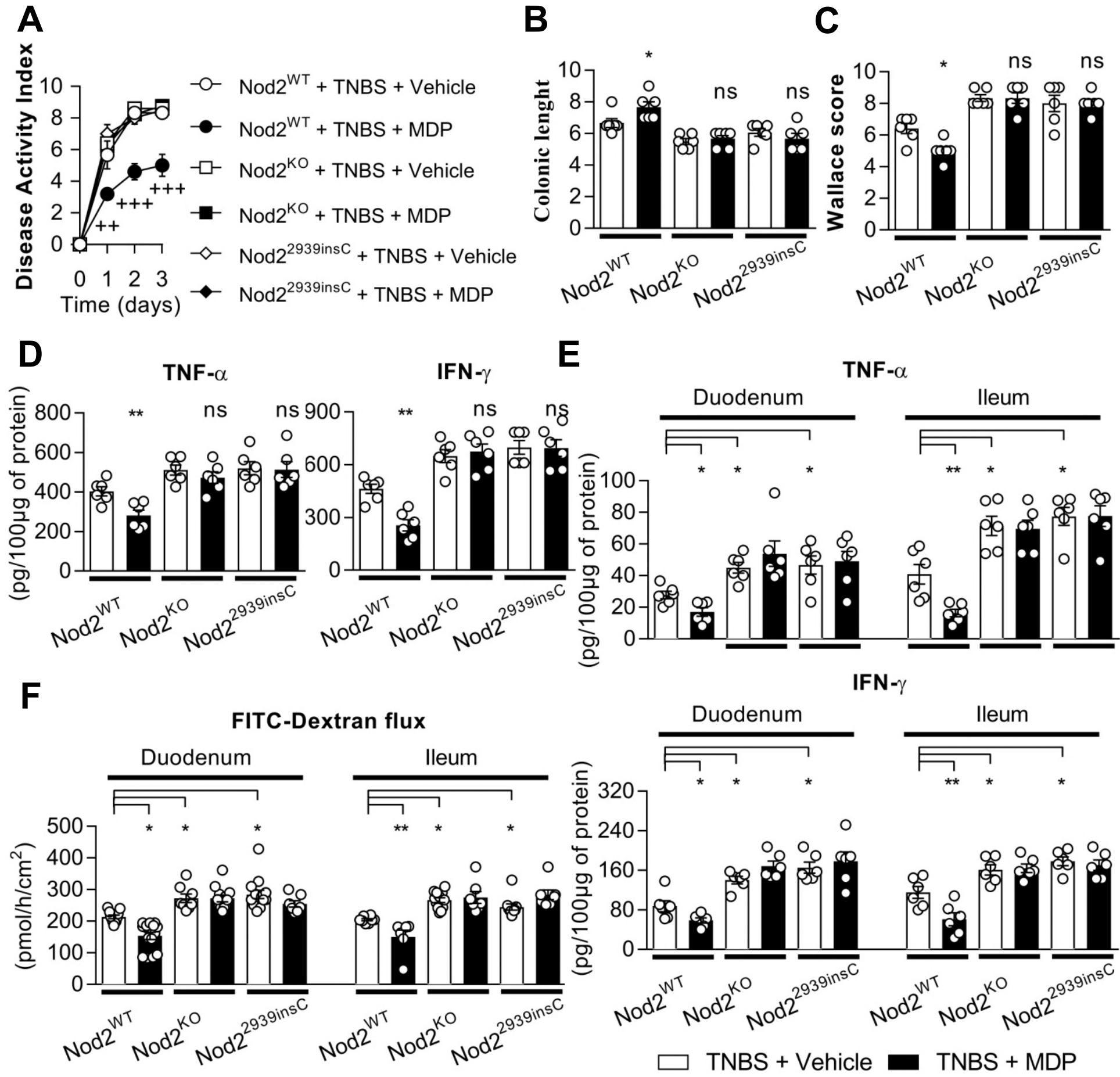

E

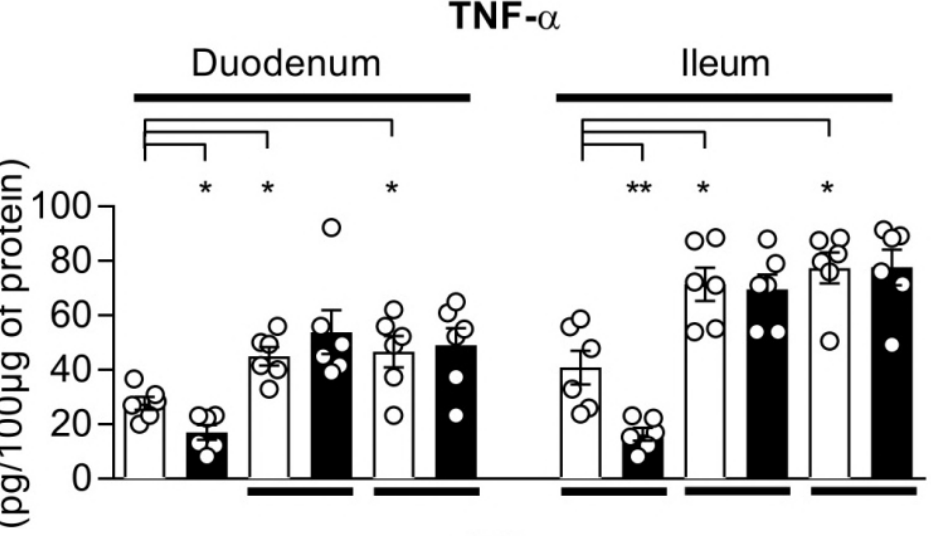

IFN- $\gamma$
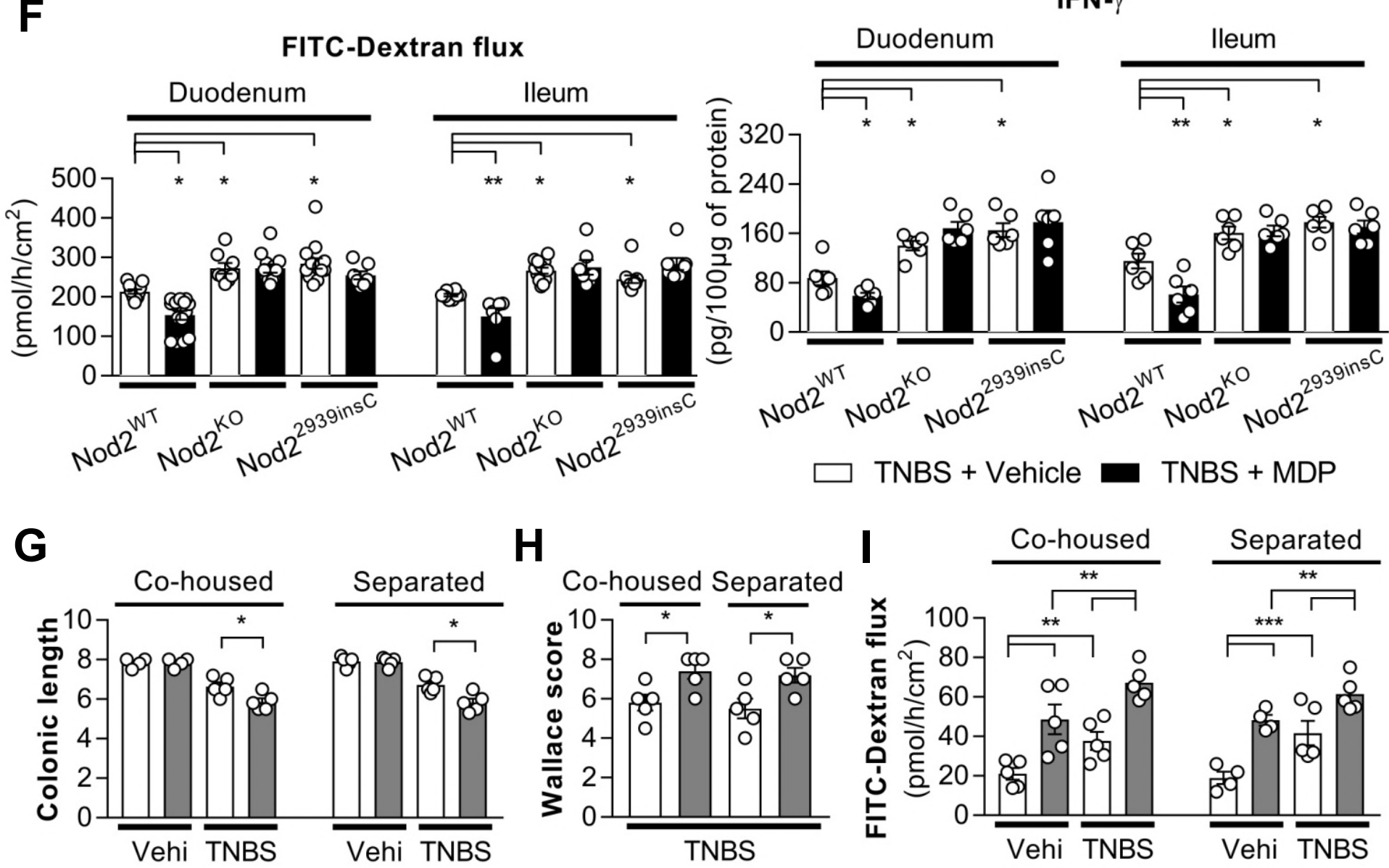

\section{$\square$ TNBS + Vehicle $\square$ TNBS + MDP}

$\square \mathrm{Nod}^{\mathrm{WT}} \square \mathrm{Nod}^{\mathrm{KO}}$ 

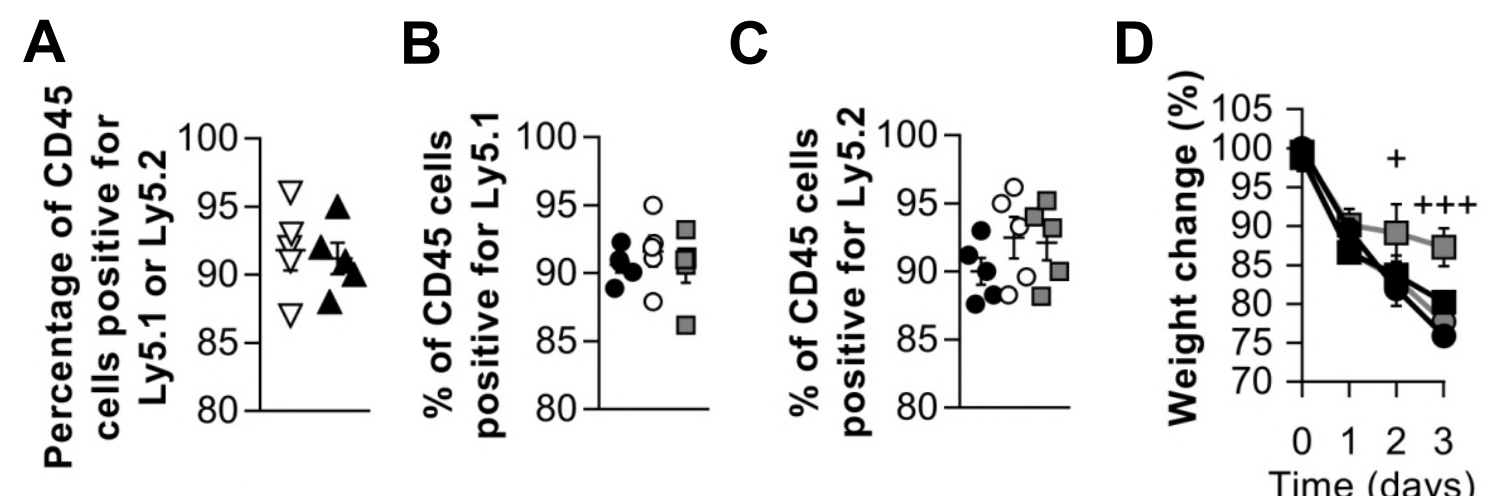

E

$\nabla \quad \operatorname{Nod}^{\mathrm{WT}}\left(\right.$ Ly5.1) $\rightarrow \mathrm{Nod}^{\mathrm{KO}}$ (Ly5.2)

Time (days)

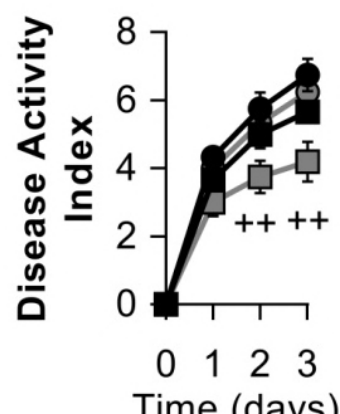

$\Delta \quad \mathrm{Nod}^{\mathrm{KO}}\left(\right.$ Ly5.2) $\rightarrow \mathrm{Nod}^{\mathrm{WT}}$ (Ly5.1)

CD19

CD3

$\mathrm{WT} \rightarrow \mathrm{WT} / \mathrm{KO}+$ Vehicle

Time (days)

$\boldsymbol{F}$

TNF- $\alpha$

G

H
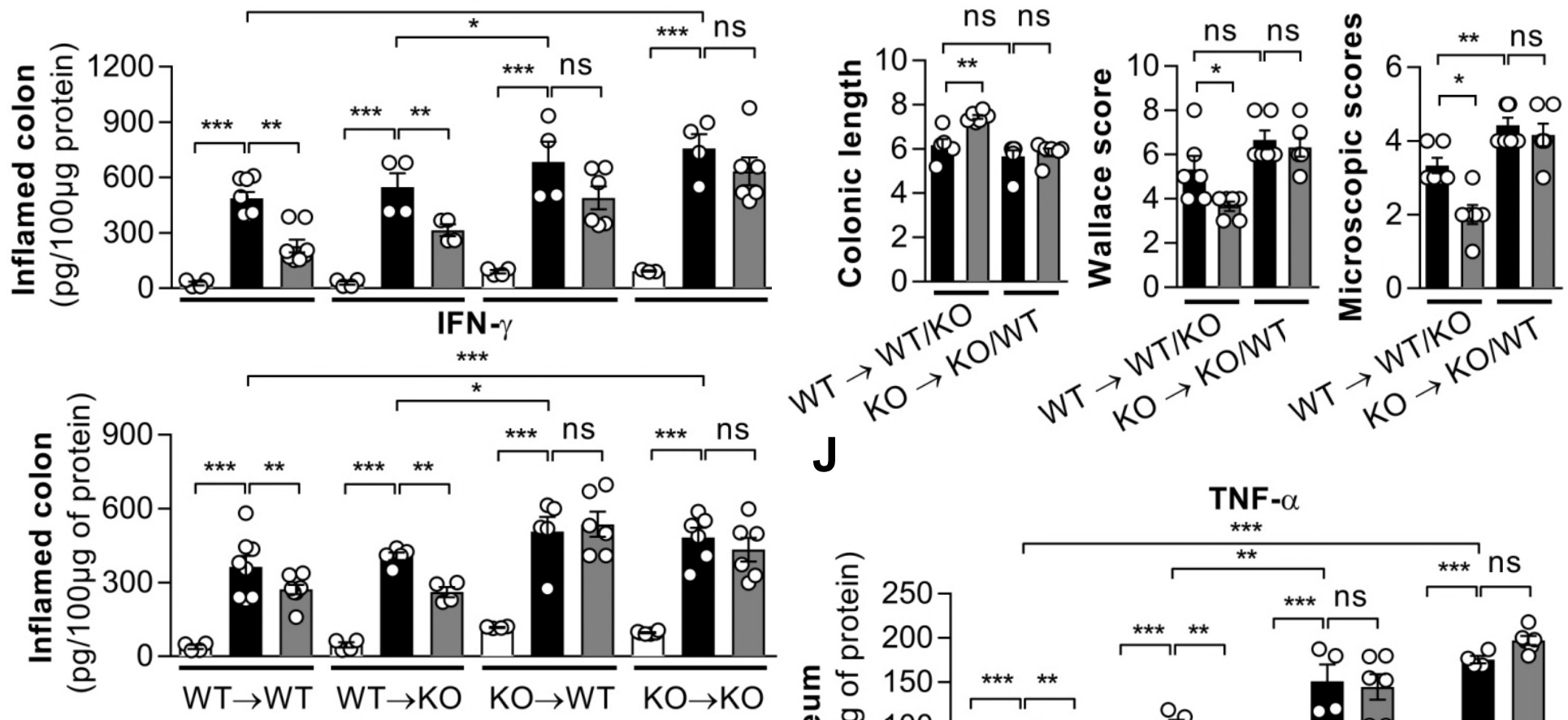

WT
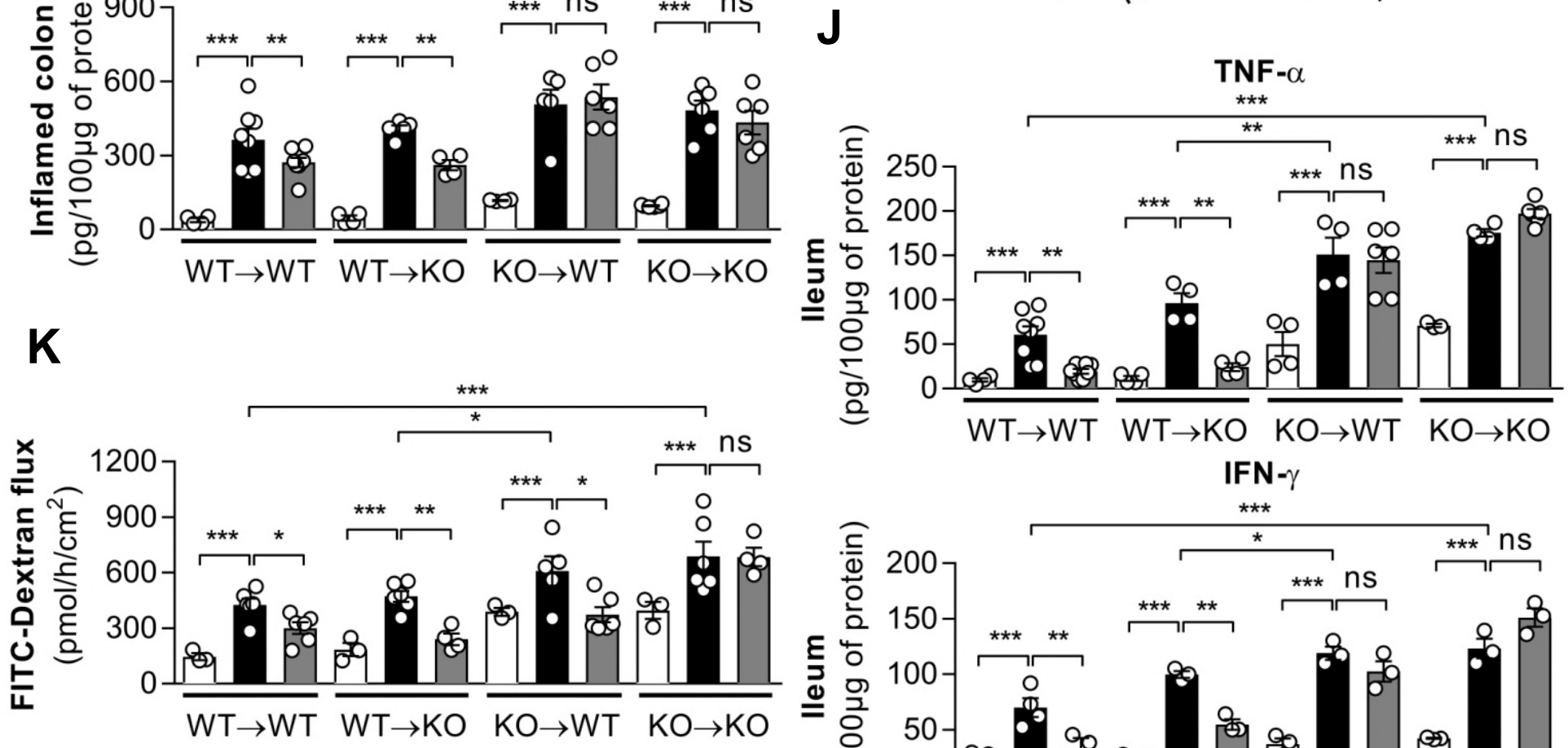

IFN- $\gamma$

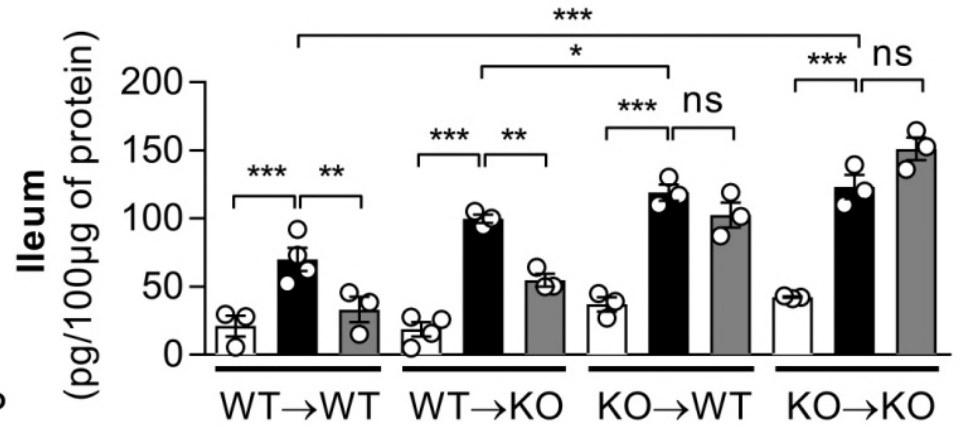

